This PDF is a selection from a published volume from the National Bureau of Economic Research

Volume Title: Producer Dynamics: New Evidence from Micro Data

Volume Author/Editor: Timothy Dunne, J. Bradford Jensen, and Mark J. Roberts, editors

Volume Publisher: University of Chicago Press

Volume ISBN: 978-0-226-17256-9

Volume URL: http://www.nber.org/books/dunn05-1

Conference Date: April 8-9, 2005

Publication Date: January 2009

Chapter Title: Ownership Change, Productivity, and Human Capital: New Evidence from Matched Employer-Employee Data

Chapter Author: Donald S. Siegel, Kenneth L. Simons, Tomas Lindstrom

Chapter URL: http://www.nber.org/chapters/c0495

Chapter pages in book: (397 - 442) 


\title{
Ownership Change, Productivity, and Human Capital \\ New Evidence from Matched Employer-Employee Data
}

\author{
Donald S. Siegel, Kenneth L. Simons, and \\ Tomas Lindstrom
}

\subsection{Introduction}

In the 1990s, there was a substantial increase in the volume of assets transferred through mergers, acquisitions, and divestitures. This trend was especially pronounced outside of the United States. Gugler et al. (2003) report that the number of deals consummated in continental Europe increased from 986 during 1981 to 1990 to 8,609 during 1991 to 1998 . The authors also note that the average value of these transactions rose from \$186.1 million in 1991 to \$414.1 million in 1998 (in constant dollars). This new wave of corporate restructuring has stimulated an important debate concerning whether these changes in ownership improve economic efficiency.

Researchers typically address this question by analyzing the impact of ownership change on short-run stock prices (event studies), long-run stock prices, or accounting profits (e.g., Ravenscraft and Scherer 1987; Jensen 1988, 1993; and McWilliams and Siegel 1997). There are several problems with the use of such performance indicators. One problem with the use of

Donald S. Siegel is a professor and dean of the School of Business at the University of Albany, SUNY. Kenneth L. Simons is an assistant professor of economics at Rensselaer Polytechnic Institute. Tomas Lindstrom is an economist at the Skandinaviska Enskilda Banken.

Paper presented at the NBER/CRIW Conference on "Producer Dynamics: New Evidence from Micro Data," Bethesda, MD, April 9, 2005. Comments from seminar participants at the University of Illinois-Urbana/Champaign, UC-Riverside, and the Network of Industrial Economists/ESRC/EPSRC Advanced Institute for Management Research Conference at the University of London, Rajshree Agarwal, John Baldwin, Eric Bartelsman, Nick Bloom, Tim Dunne, Rachel Griffith, John Haltiwanger, Rupert Harrison, Jonathan Haskel, Brad Jensen, Joe Mahoney, Pedro Martins, Mark Roberts, Anju Seth, and especially Judith Hellerstein, are greatly appreciated. 
stock prices is that many economists question the validity of the efficient markets hypothesis (see Shleifer 2001), which conjectures that changes in share prices following announcements of ownership changes reflect changes in future real economic performance. This is a critical issue, since market efficiency provides the basis for use of the event study methodology. Furthermore, McWilliams and Siegel (1997) have demonstrated that inadequate attention has been paid to research design issues in many event studies in the management literature. Accounting profitability has long been known to be an imperfect measure of economic performance (see Fisher and McGowan 1983).

Policy decisions regarding the optimal level of ownership change should be based on analysis of the effects of these transactions on economic efficiency. It is also important to note that many ownership changes involve privately-held companies or occur below the firm level (e.g., divisions of large, publicly-traded firms), which makes it virtually impossible to assess stock price or accounting profitability effects, except for those transactions involving large, publicly-traded firms. The end result is that analyses of ownership changes based solely on information from public companies could yield misleading estimates of the antecedents and consequences of ownership changes.

To overcome these limitations, several authors (e.g., Lichtenberg and Siegel 1987, 1990a, 1990b; McGuckin and Nguyen 1995; Maksimovic and Phillips 2001; Harris, Siegel, and Wright 2005) have asserted that a more desirable methodology is to assess the total factor productivity (TFP) of plants before and after ownership changes. Empirical evidence from the United States has been derived from the Census Bureau's Longitudinal Research Database (LRD). ${ }^{1}$ The LRD is a plant-level file constructed by linking information from the quinquennial Census of Manufactures and the Annual Survey of Manufactures. Empirical evidence from the United Kingdom has been derived from the Annual Respondents Database (ARD). The ARD consists of plant-level records from the U.K. Annual Census of Production. Several of these studies have been based on restricted samples (e.g., a sample consisting mainly of long-lived plants or the universe of plants in one or two industries), which potentially limits the ability to generalize from these findings.

From a welfare perspective, it is also interesting to examine how ownership change relates to characteristics of the workforce. Existing plant-level studies are constrained by having aggregate data on workers at the establishment and limited information on the composition of the workforce. That is, while authors can make inferences regarding the effects of ownership change on the average worker at the plant, they cannot follow individ-

1. Excellent reviews of LRD-based studies are presented in Caves (1998) and Bartelsman and Doms (2000). 
ual employees at these establishments or analyze detailed changes in the composition of human capital that arise in the aftermath of ownership change.

As a result, these studies have provided limited evidence on how changes in corporate control affect the demand for different types of workers. For example, policy makers might wish to consider the impact of ownership change on male versus female, Swedish-born versus immigrant, young versus old, and highly-educated versus non-highly-educated workers. The use of matched employer-employee data also enables us to directly explore the dynamics of workforce/human capital adjustment at the establishments involved in such transactions, in the sense that we can track the movement and relative compensation of employees who experienced an ownership change.

The purpose of this study is to fill these gaps by relating productivity patterns associated with ownership change to numerous worker characteristics. Our empirical analysis is based on matched employer-employee data for over 19,000 Swedish manufacturing establishments, which constitute the majority of that nation's population of manufacturing plants, for the years 1985 to 1998 . Our sample also includes information on every worker in those plants, along with their complete work history during this fourteenyear period.

We also assess whether there are differential effects on productivity for different types of ownership changes: partial and full acquisitions and divestitures, and unrelated and related diversification. Finally, we present the first plant-level findings from continental Europe and analyze more recent data on ownership change.

The remainder of this chapter is organized as follows. Section 11.2 provides a review and critique of existing plant-level studies of the consequences of ownership change. A discussion of various theories relating to the impact of ownership change on economic performance is presented in section 11.3. Section 11.4 describes the construction of the micro data set and its salient characteristics. Section 11.5 outlines the econometric methodology. Section 11.6 presents empirical results. The final section, 11.7 , contains preliminary conclusions.

\subsection{Review and Critique of Plant-Level Studies of the Relationship between Ownership Change, Productivity, and Labor Demand}

\subsubsection{Productivity}

Table 11.1 presents a summary of plant-level studies of the relationship between ownership change and productivity. Several stylized facts emerge from this table. The first is that there have been no studies based on evidence from continental Europe. Second, most authors report that plants 


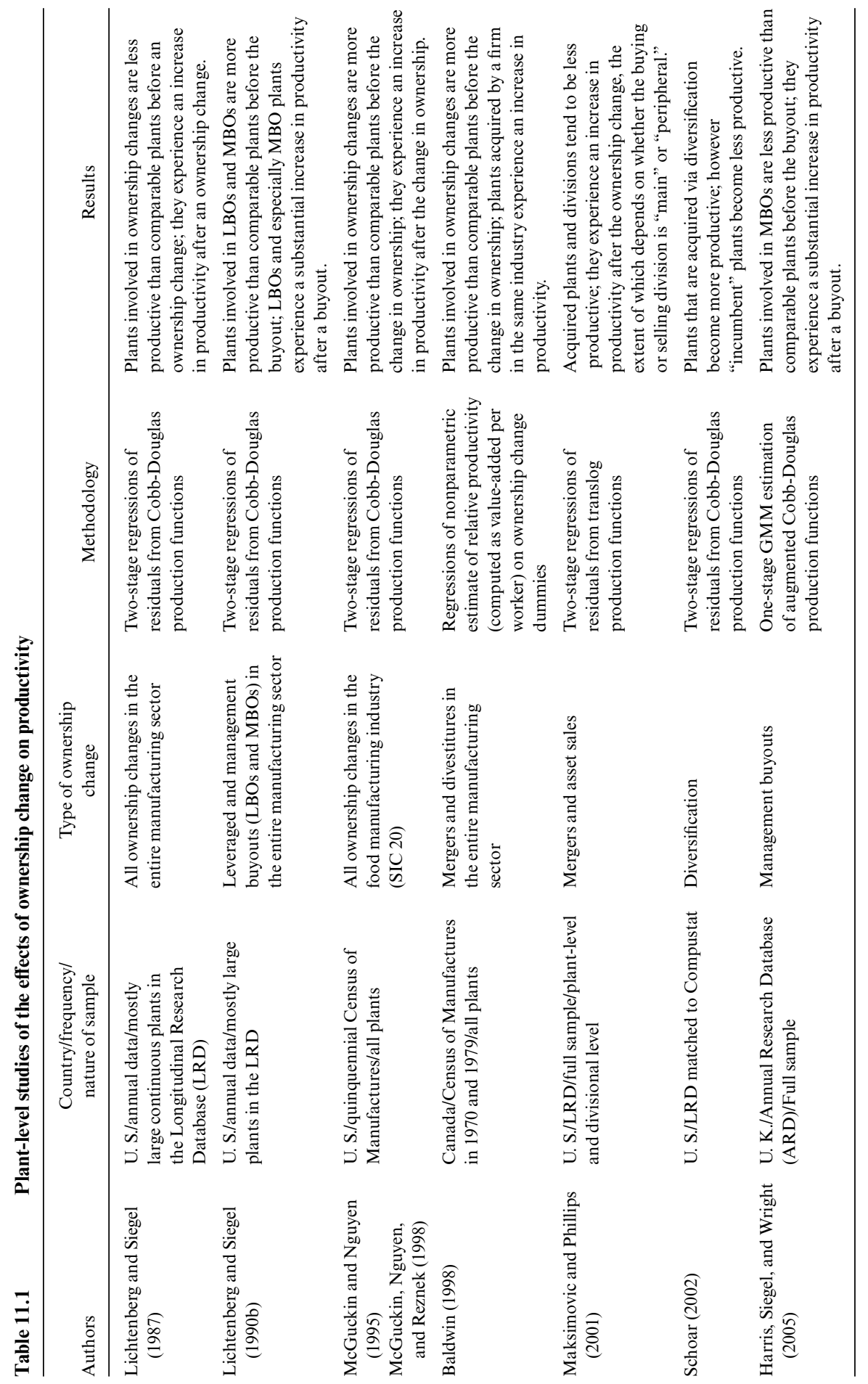


involved in an ownership change experience an improvement in productivity after the change in ownership. Third, the magnitude of the productivity increase appears to vary by type of ownership change (e.g., leveraged buyouts versus management buyouts), which underscores the importance of disaggregating ownership change. Fourth, evidence on relative productivity before ownership change is mixed. Some authors report that plants involved in ownership changes are less productive than comparable plants before the change in ownership, while others report the opposite.

These mixed results could be due to differences in the nature of the samples and the time frames of the analyses. Some authors have analyzed mostly large plants (e.g., Lichtenberg and Siegel 1987, 1990b), while others have focused on a single industry (e.g., McGuckin and Nguyen 1995). Several papers use quinquennial Census of Manufactures data, which makes it difficult to analyze timing effects with sufficient precision. This is potentially important since studies based on annual data indicate that major changes occur soon after the change in ownership.

The first plant-level study of the relationship between ownership change and TFP was Lichtenberg and Siegel (1987), based on a (mostly) balanced panel of 20,493 U.S. LRD establishments in 450 manufacturing industries. In subsequent empirical work (Lichtenberg and Siegel 1990a, 1990b), the authors were able to analyze a more unbalanced sample of LRD plants. Their econometric analysis was based on the following two-stage approach. In the first stage, the authors computed residuals from within-industry (four-digit Standard Industrial Classification [SIC]) OLS regressions of log-linear Cobb-Douglas production functions of the following form (with error term suppressed):

$$
\ln Q_{i t}=\beta_{1} \ln K_{i t}+\beta_{2} \ln L_{i t}+\beta_{3} \ln M_{i t}
$$

where $Q_{i t}, K_{i t}, L_{i t}$, and $M_{i t}$ refer to output, capital, labor, and materials, respectively, in plant $i$ and year $t$. The residuals from equation (1) can be interpreted as an estimate of the relative productivity of each plant (i.e., relative to plants in the same industry). In the second stage of their model, the authors regressed the productivity residuals on a set of dummy variables denoting whether the plant had changed owners:

$$
R E L P R O D_{i t}=f\left(O C_{i t+s}\right)
$$

where $R E L P R O D_{i t}$ is the productivity residual of plant $i$ in year $t$, the error term is again suppressed, and $O C_{i t+s}$ is a dummy variable that equals 1 if plant $i$ was involved in an ownership change in year $t+s$ (where $s$ can be negative or positive) or 0 otherwise.

McGuckin and Nguyen (1995) conducted a similar analysis of the effects of ownership change on economic efficiency, based on the complete population of plants in the food manufacturing industry (SIC 20) in the U.S. Census of Manufactures. They used the same method as in the previous 
LRD-based studies to construct estimates of relative TFP, as well as labor productivity. However, they did not employ precisely the same second-stage approach, since they do not observe annual ownership changes, only those occurring between the quinquennial Census of Manufactures.

Maksimovic and Phillips (2001) computed similar measures of relative TFP, based on the following translog production function (error term suppressed):

$$
\begin{aligned}
\ln Q_{i t}= & \alpha_{i}+\beta_{1} \ln K_{i t}+\beta_{2} \ln L_{i t}+\beta_{3} \ln M_{i t}+\beta_{4}\left(\ln K_{i t}\right)^{2} \\
& +\beta_{5}\left(\ln L_{i t}\right)^{2}+\beta_{6}\left(\ln M_{i t}\right)^{2}+\beta_{7} \ln K_{i t} \ln L_{i t} \\
& +\beta_{8} \ln K_{i t} \ln M_{i t}+\beta_{9} \ln L_{i t} \ln M_{i t}+\beta_{10} A G E_{i t}+\mu_{t}
\end{aligned}
$$

where $\alpha_{i}$ is a plant-specific fixed effect, $\mu_{t}$ is a technology shift parameter, and $A G E_{i t}$ denotes the age of the plant.

Table 11.1 reveals that most authors have used a two-stage method to assess the antecedents and consequences of ownership change. In contrast, we estimate within industry (four-digit SIC), one-stage, augmented CobbDouglas production functions. We also experimented with using similar one-stage translog production functions, and found that this had little effect on our econometric results.

\subsubsection{Labor Demand}

Table 11.2 summarizes plant and firm-level studies of the impact of ownership change on employment and earnings. Much of the plant-level evidence seems to indicate that ownership change does not result in statistically significant declines in the employment and earnings of production workers at production establishments. In fact, the most comprehensive evidence, presented in McGuckin and Nguyen (2001), suggests that earnings and employment increase after ownership change. On the other hand, Lichtenberg and Siegel (1990a) find that employment and wage growth are lower in central office or auxiliary establishments in the aftermath of an ownership change, suggesting that white-collar workers suffer more than blue-collar employees when such transactions occur.

Table 11.2 also reveals that these effects vary by type of ownership change. For instance, Baldwin (1998) reported that mergers had a negative impact on the employment and compensation of nonproduction workers. Similar patterns emerge in the aftermath of leveraged and management buyouts. Bhagat, Shleifer, and Vishny (1990) find that 45 percent of the firms involved in hostile takeovers laid off workers, affecting about 6 percent of the workforce.

To the best of our knowledge, there have been no empirical studies of the impact of the effects of ownership change on the demand for different types of workers (e.g., men versus women, Swedish-born versus immigrant, younger versus older, highly-educated versus non-highly-educated). In the 


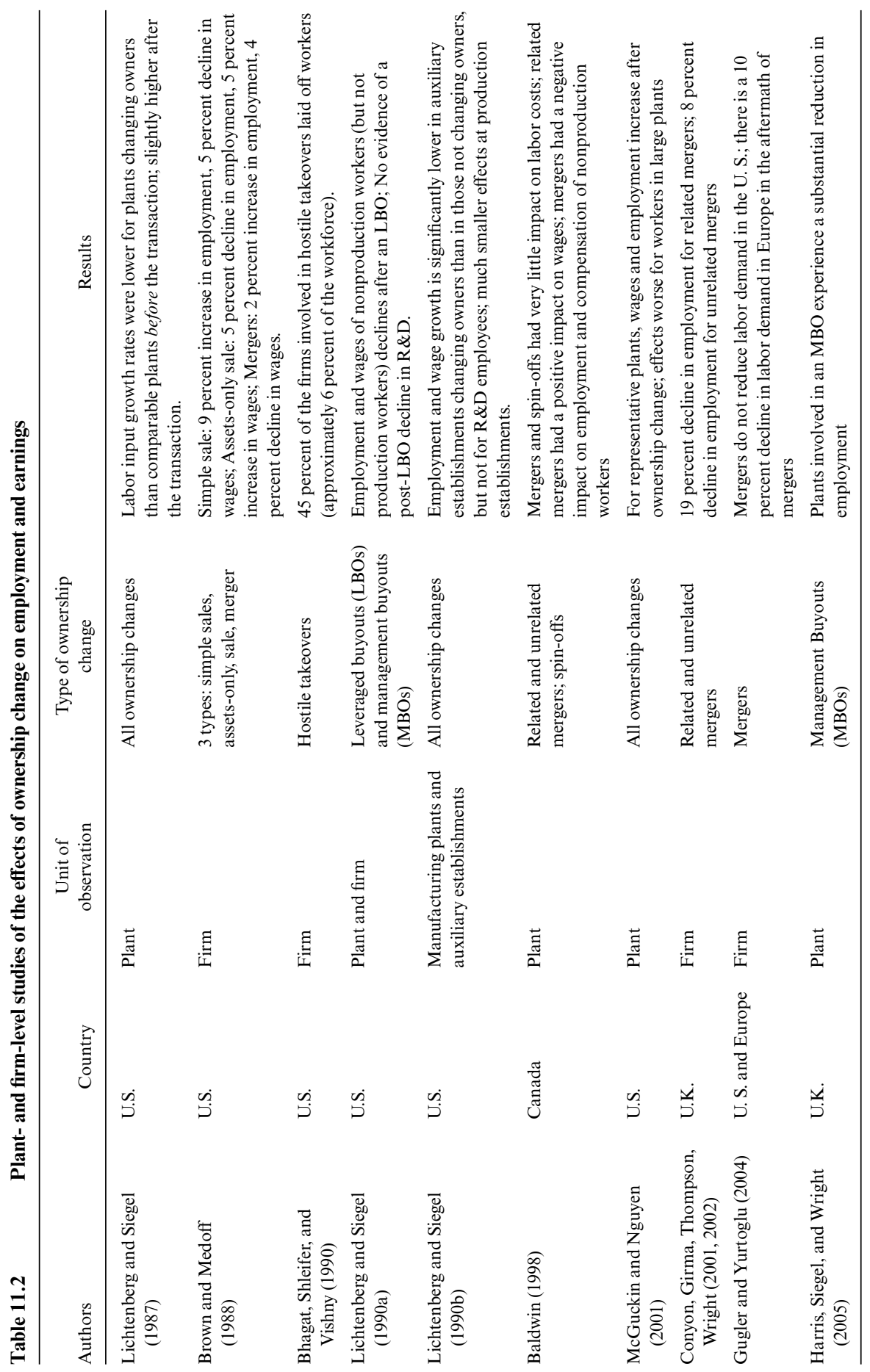


following section, we provide a brief summary of theories relating to the impact of ownership change on performance.

\subsection{Brief Review of Theories of the Impact of Ownership Change on Economic Performance}

Scholars have proposed numerous theories relating to the antecedents and consequences of changes in ownership. Several authors have asserted that corporate control changes reduce firm performance. This class of theories usually focuses on several managerial flaws. For instance, Dennis Mueller (1969) hypothesizes that managers attempt to maximize growth instead of shareholder wealth. This leads corporate executives to adopt policies that benefit them financially and professionally, at the expense of profit or shareholder wealth maximization. Unfortunately, these actions could lead to expansion of the firm beyond an optimal point.

In a similar vein, Richard Roll (1986) and Mathew Hayward and Donald Hambrick (1997) argue that the hubris of CEOs and other managers causes them to systematically overestimate their ability to manage the companies they wish to acquire. According to this view, overconfidence induces managers to overpay for target firms, resulting in a decline in the economic performance of the acquirer.

Michael Gort (1969) advanced a theory predicting that ownership change has a neutral impact on economic performance. In his framework, ownership change is induced by divergent expectations between buyers and sellers regarding the future value of corporate assets. He also seeks to explain fluctuations in merger activity over time. Thus, his model predicts that the magnitude of differences in buyer and seller expectations of the share prices of target firms is likely to be higher during periods of economic disturbance, which he defines as periods of sustained share price increases or when firms experience rapid technological change. Note that Gort's model is a variation of the familiar theme of stockholder wealth maximization. That is, he assumes that the market expects no gain to result from the merger because acquirers have different expectations than the market. Therefore, the premium earned by the acquired firm is exactly offset by a loss to the acquiring firm's shareholders.

Several theories predict that ownership change has a positive effect on economic performance. James Meade (1968) asserted that takeovers are part of a process of natural selection, whereby efficient managers are rewarded through survival, while inefficient managers are punished via takeovers. According to Henry Manne (1965) and Michael Jensen (1988), the takeover threat constrains the self-serving behavior of managers, and induces them to pursue profit-maximizing strategies. Jensen (1993) extends this theory by noting that certain types of ownership changes (e.g., management buyouts) result in changes in governance and incentive structures 
that reduce agency costs. These agency costs could be substantial in large corporations, where there is considerable separation of ownership and control.

Frank Lichtenberg and Donald Siegel (1987) advanced a matching theory of ownership change, in which the fit between heterogeneous plants and owners is reflected in productivity. The matching theory of ownership change borrows heavily from the theory of labor turnover or job separation proposed by Jovanovic (1979). In the Lichtenberg and Siegel framework, low productivity signals a bad match, which is the key determinant of the firm-level decision to maintain or relinquish ownership of a given plant. The model has two empirical implications. The first is that the lower the productivity of a plant, relative to average productivity in its industry, the higher is the probability of an ownership change. A second implication of the model is that when an ownership change occurs, even an average match can be expected to lead to above average productivity growth because a better match will result.

Thomas Holmes and James Schmitz (1990) outlined an equilibrium model of ownership change (or business transfer) that pertains mainly to smaller firms. In their model, high quality managers buy companies that implement high quality projects based on new ideas. Jovanovic and Rousseau (2002) also assert that high quality projects and high quality managers are complements. Moreover, they assert that mergers and takeovers play a role in spreading new technologies and reallocating capital to more efficient uses and to better managers. Thus, according to the authors, ownership change plays a role that is similar to the efficiency-enhancing, dynamic adjustment associated with entry and exit. The notion that technological change and ownership change are complements suggests that these transactions should result in a decline in employment and skill upgrading. ${ }^{2}$

Many of the previously mentioned theories of ownership change do not have obvious implications for changes in the workforce below the top management level. Indeed, for ownership changes that occur according to the logic of the theories advanced by Mueller, Roll, Hayward and Hambrick, and Gort, we might be surprised to observe any substantial changes in a plant's workforce in the aftermath of ownership change. In contrast, at least some of the theories that predict an improvement in productivity suggest that this enhancement may arise due to new managers' changes to the workforce. Indeed, the theory of Jovanovic and Rousseau specifically addresses such changes. Thus, evidence on the degree to which workforce changes occur may shed light on the relative merit of the aforementioned theories of ownership change.

2. There is considerable evidence in the literature on skill-biased technological change (see Siegel [1999] and Link and Siegel [2007] for comprehensive reviews of this literature) that technological change is associated with downsizing and skill-upgrading of the workforce. 
In the following section, we describe the data set that allows us to assess the impact of ownership on performance and workforce characteristics.

\subsection{Data}

Our empirical analysis is based on a special file that links detailed information on Swedish workers and the establishments that employ them. This file has data on the output and inputs of these plants, which enables us to construct estimates of total factor productivity (TFP). It also contains information on a wide variety of worker characteristics, such as level of education, age, gender, and national origin.

\subsubsection{Plants}

The primary unit of observation in our study is the plant. Following conventional international standards, the plant or establishment is defined as a physically independent unit within a firm. It is assumed that each plant focuses on just one line of business (i.e., one activity). If a company is involved in multiple activities at the same physical address, the firm is asked to report separate figures for each activity. Each figure is then tied to a separate plant or sometimes recorded under the plant's largest activity. In most cases, however, firms focus on a single activity, implying that the local units are seldom split into several plants. Plants that were considered to be nonactive and help plants, such as sales offices (or what would be considered auxiliary establishments in the United States), were also excluded from the data.

According to Swedish law, each business is required to report information to Statistics Sweden on an annual basis. In 1946, the certainty criterion for inclusion in the annual survey of manufacturing plants was established at a minimum of five employees and 10,000 SEK (about 1,300 U.S. dollars) in production value. In 1990, this certainty threshold was raised to a minimum of ten employees, while a sampling procedure is applied to the smaller plants. In 1997, the certainty threshold officially was raised to a minimum of twenty employees, but as will be seen shortly, evolving sampling procedures for smaller plants meant that this change had little effect. ${ }^{3}$

Tables 11.3 and 11.4 compare our sample of 19,010 plants to the population of Swedish manufacturing establishments. Table 11.3 contrasts the size distribution of our sample (top panel) with the corresponding size distribution for the population of Swedish manufacturing plants (bottom panel) in 1986, 1990, and 1995. These figures reveal that our sample is not completely representative in terms of size, since it is more heavily weighted towards plants with more than ten employees. On the other hand, table

3. We have a small number of mining plants in our sample. The threshold increases in 1990 , and 1997 only affected manufacturing plants. 


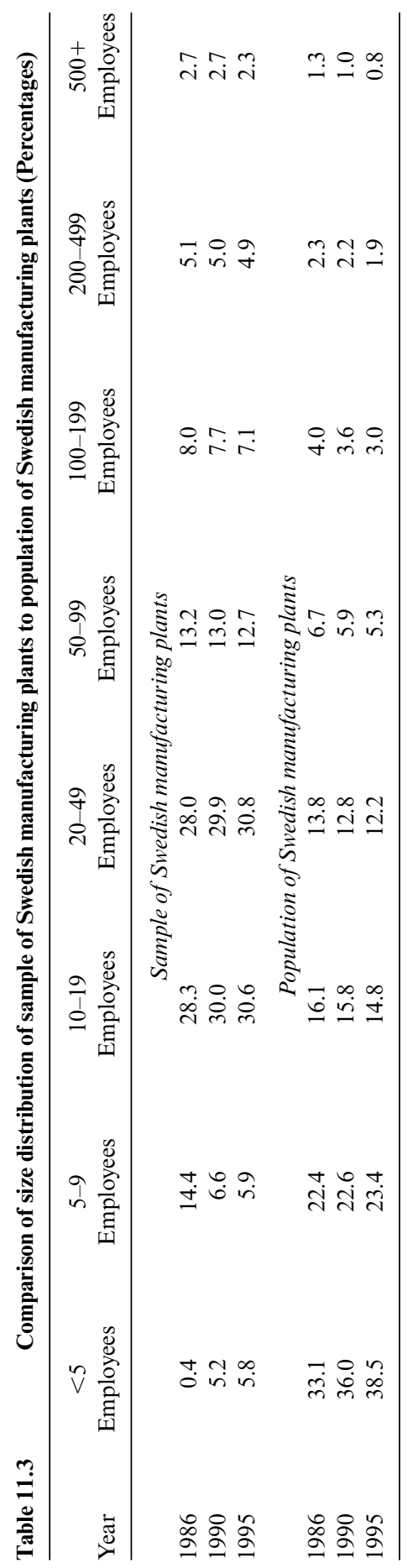


Table 11.4

Sample plants $(N=19,010)$ relative to population of Swedish manufacturing plants

\begin{tabular}{lccc}
\hline Variable & 1986 & 1990 & 1995 \\
\hline $\begin{array}{l}\% \text { of plants with more than 20 employees included } \\
\quad \text { in our sample }\end{array}$ & $85.6 \%$ & $91.2 \%$ & $94.5 \%$ \\
$\begin{array}{l}\text { \% of total employment in plants with more than } \\
\quad \text { 20 employees included in our sample }\end{array}$ & $92.0 \%$ & $95.7 \%$ & $98.6 \%$ \\
$\begin{array}{l}\text { \% of plants with more than 10 employees included } \\
\quad \text { in our sample }\end{array}$ & $79.8 \%$ & $84.3 \%$ & $87.5 \%$ \\
$\begin{array}{l}\text { \% of total employment in plants with more than 10 } \\
\quad \text { employees included in our sample }\end{array}$ & $89.7 \%$ & $92.4 \%$ & $94.7 \%$ \\
$\begin{array}{l}\% \text { of plants with more than 5 employees included } \\
\text { in our sample }\end{array}$ & $63.6 \%$ & $62.9 \%$ & $62.4 \%$ \\
$\begin{array}{l}\% \text { of total employment in plants with more than } \\
\text { 5 employees included in our sample }\end{array}$ & $84.9 \%$ & $87.0 \%$ & $90.7 \%$ \\
\hline
\end{tabular}

11.4 indicates that the sample constitutes a large fraction of economic activity in the manufacturing sector, especially for plants with more than ten employees.

\subsubsection{Ownership Change}

Table 11.5 presents statistics on the incidence of ownership change. Over the entire sample period (1985 to 1998), 5.1 percent of plants experienced at least one ownership change. These rates of plant turnover appear to be slightly higher when they are weighted by value-added and employment (columns 2 and 3). An analysis of the annual figures reveals that the incidence of ownership change appears to have risen during the late 1980s, reaching a peak in the early 1990s.

In table 11.6, we present evidence on the incidence of several types of ownership change involving our sample of plants during the sample period (1986 to 1998). We can identify whether an acquisition or divestiture involves the buying or selling of an entire firm. Note that the overwhelming majority of such changes are full acquisitions or divestitures, although the relative importance of such transactions diminishes when they are weighted by value-added or employment (columns 2 and 3). The full and partial acquisition categories indicate whether all or part of a firm is acquired: 4.2 percent of plants in a year changed owners as part of a full-firm takeover, and 0.9 percent changed owners through a part-firm takeover, summing to the total annual figure of 5.1 percent. The full and partial divestiture categories indicate whether the original owner ceded ownership of all versus some plants in a firm, regardless of the new owner(s) of those plants. We have also identified whether the buyer had existing plants in the same (four-digit) industry, which we refer to as a related acquisition. 
Table 11.5

Incidence of ownership change for 19,010 Swedish manufacturing plants (1986-1998)

\begin{tabular}{lccc}
\hline Year & $\begin{array}{c}\text { \% of plants } \\
\text { involved in a } \\
\text { ownership change }\end{array}$ & $\begin{array}{c}\text { \% of value-added } \\
\text { involved in an } \\
\text { ownership change }\end{array}$ & $\begin{array}{c}\% \text { of employment } \\
\text { involved in an } \\
\text { ownership change }\end{array}$ \\
\hline 1986 & $3.2 \%$ & $3.1 \%$ & $3.3 \%$ \\
1987 & $4.3 \%$ & $5.2 \%$ & $5.7 \%$ \\
1988 & $5.5 \%$ & $8.3 \%$ & $7.5 \%$ \\
1989 & $5.0 \%$ & $5.1 \%$ & $5.6 \%$ \\
1990 & $4.8 \%$ & $7.7 \%$ & $8.2 \%$ \\
1991 & $4.8 \%$ & $7.8 \%$ & $7.4 \%$ \\
1992 & $5.6 \%$ & $5.0 \%$ & $5.7 \%$ \\
1993 & $6.0 \%$ & $4.7 \%$ & $5.2 \%$ \\
1994 & $4.6 \%$ & $7.3 \%$ & $6.7 \%$ \\
1995 & $3.9 \%$ & $2.1 \%$ & $5.3 \%$ \\
1997 & $3.9 \%$ & $4.7 \%$ & $3.1 \%$ \\
1998 & $3.7 \%$ & $2.3 \%$ & $3.8 \%$ \\
Entire period & $3.2 \%$ & $5.4 \%$ & $3.0 \%$ \\
\hline
\end{tabular}

Incidence of ownership change for 19,010 Swedish manufacturing plants (1986-1998) by type of ownership change

\begin{tabular}{lccc}
\hline Type of ownership change & $\begin{array}{c}\text { \% of plants } \\
\text { involved in a } \\
\text { particular type of } \\
\text { ownership change }\end{array}$ & $\begin{array}{c}\% \text { of value-added } \\
\text { involved in a } \\
\text { particular type of } \\
\text { ownership change }\end{array}$ & $\begin{array}{c}\% \text { of employment } \\
\text { involved in a } \\
\text { particular type of } \\
\text { ownership change }\end{array}$ \\
\hline All ownership changes & $5.1 \%$ & $5.3 \%$ & $5.6 \%$ \\
Full acquisition & $4.2 \%$ & $2.7 \%$ & $3.2 \%$ \\
Partial acquisition & $0.9 \%$ & $2.6 \%$ & $2.4 \%$ \\
Full divestiture & $4.5 \%$ & $3.3 \%$ & $3.9 \%$ \\
Partial divestiture & $0.7 \%$ & $2.0 \%$ & $1.8 \%$ \\
Related acquisition & $0.9 \%$ & $1.2 \%$ & $1.4 \%$ \\
Unrelated acquisition & $0.6 \%$ & $0.8 \%$ & $0.6 \%$ \\
Change in ownership involving & $3.7 \%$ & $3.4 \%$ & $3.7 \%$ \\
\hline a single firm & & & \\
\hline
\end{tabular}

\subsubsection{Capital}

A critical issue in the calculation of total factor productivity (TFP) is construction of a capital measure. Some researchers avoid analyzing TFP and instead compute labor productivity (LP), which is easier to measure. We will present econometric results based on both TFP and LP. We calculated estimates of the capital stock as follows: initial values of capital were estimated in 1989, based on the assumption of a constant capital-to-sales 
ratio across all plants in each two-digit SIC industry. Using these initial estimates, capital is constructed using the usual perpetual inventory algorithm, $K_{i t}^{c}=\left(1-\delta^{c}\right) K_{i t-1}^{c}+\rho_{t} I_{i t}^{c}$, where $i$ denotes a plant, $t$ denotes a year, $c$ is either machinery or buildings and land, $K$ denotes capital, $I$ denotes investment, $\delta$ denotes the depreciation rate, and $\rho$ denotes an investment deflator. ${ }^{4}$ The capital estimates for machinery, plus buildings and land were summed to create a single combined capital stock measure, $K_{i t}$.

\subsubsection{Employees}

Matched employee-level data come from a database on the jobs and earnings of every employee in Sweden. The data are based on tax filings and hence record each employee's annual earnings, which distinguish yearlong work-related earnings from other earnings. ${ }^{5}$ Employment is recorded in November of each year, and the records match employees (with a tiny percentage of missing cases among our manufacturing employees) to specific plants, firms, and (five-digit SIC) industries. Because the database covers all employees as needed for relevant tax records, we are able to infer that any employee whose record is missing in a given year was not employed in Sweden in that year. The full database contains 36,398,617 records across the fourteen years of data from 1985 to 1998, for an average of 2.6 million workers per year, consistent with the Swedish population of close to 9 million. Among all of the records, 9,251,962 records pertain to cases in which a person is employed by a manufacturing plant in our sample during the relevant year.

The employee data include information on the gender, national origin, year of birth, most recent year of education, and number of years of education for each employee. We use this information to construct measures at the plant and employee levels of workforce characteristics. At the plant level, we assess (in each year) the percentage of workers who are male versus female, the percentage who were born in Sweden versus immigrated, the mean age of employees, mean years of experience (as proxied by the number of years elapsed since their last year of education), and the percentage of employees with at least some college-level education. At the employee level, we assess (in each year) the gender of the employee, whether he or she was born in Sweden, was below or above the mean age, below or above the mean level of experience, and determine educational status based on the following four categories: (a) less than a high school educa-

4. The depreciation rate for machinery was allowed to differ by three-digit SIC industry and was taken from figures of the OECD, while a constant figure of 0.0314 was used for buildings and land. Investments were deflated using manufacturing sector-wide annual investment deflators reported by Statistics Sweden. We rely on figures kindly provided by M. Carlsson and replicate and extend the methods he used.

5. The data do not include hours worked or hourly wages, only the employee's annual total income from employment. 
tion (up to ten years apparently equivalent to U.S. grade 8), (b) high school education (up to fourteen years apparently equivalent to U.S. grade 12), (c) at least some college or technical school education, and (d) at least some $\mathrm{PhD}$-level studies. For our analysis of employee turnover in the aftermath of ownership change (where do old employees go and where do new employees come from), we also assessed whether employees transitioned to jobs in the same four-digit SIC industry versus jobs in other manufacturing or nonmanufacturing industries, and whether each employee was working in Sweden in each year. ${ }^{6}$

\subsection{Econometric Models}

\subsubsection{Types of Models}

In this version of the chapter, we estimate two types of models. For analyses of labor and total factor productivity,

$$
\ln Q_{i t}=f_{i t}+\omega_{i t}
$$

where $Q_{i t}$ denotes plant $i$ 's output in year $t, f_{i t}$ is the logarithm of plant $i$ 's production function in year $t$, and $\omega_{i t}$ is an efficiency residual. The efficiency residual is assumed to be influenced by ownership change and other variables, as follows:

$$
\omega_{i t}=\sum_{s=-13}^{12} \gamma_{s} O C_{i t-s}+\boldsymbol{\delta}^{\prime} \mathbf{x}_{i t}+\varepsilon_{i t}
$$

where $\Sigma_{s=-13}^{12} \gamma_{s} O C_{i t-s}$ parameterizes the relation to ownership change as discussed in the following, $\boldsymbol{\delta}$ is a vector of coefficients, $\mathbf{x}_{i t}$ is a vector of control variables for plant $i$ in year $t$, and $\varepsilon_{i t}$ is the remaining efficiency residual. Rewriting (4) thus yields

$$
\ln Q_{i t}=f_{i t}+\sum_{s=-13}^{12} \gamma_{s} O C_{i t-s}+\boldsymbol{\delta}^{\prime} \mathbf{x}_{i t}+\varepsilon_{i t} .
$$

Other analyses, which are not based on estimation of a production function, assume the same form:

$$
y_{i t}=\alpha+\sum_{s=-13}^{12} \gamma_{s} O C_{i t-s}+\delta^{\prime} \mathbf{x}_{i t}+\varepsilon_{i t} .
$$

where $y_{i t}$ is the dependent variable in question (e.g., employment or earnings), $\alpha$ is an intercept parameter, and the other terms are as defined previously.

6. Employees' four-digit SIC industries of employment were assessed using 1969 SICs where possible, for comparability with the plant-level analyses. However, 1969 SICs were not available in all years of data, so 1992 SICs were used to assess industry of employment when 1969 SICs were not available in both the year in question and the comparator year. 


\subsubsection{Ownership Change}

The treatment of ownership change in the econometric analysis requires careful consideration. In equations (5) through (7), $s$ denotes the year relative to the year of ownership change, so that negative values of $s$ signify years preceding ownership change, $s=0$ denotes the year during which the plant changed owners, and positive values of $s$ pertain to years following ownership change. A dummy variable $O C_{i t-s}$ equals 1 if plant $i$ 's owner changed (with certainty) $s$ years preceding the current year $t$ for $s \geq 0$, or $|s|$ years following the current year for $s<0$, or 0 otherwise. Note that our sample allows us to identify each plant's owner for the years 1985 through 1998, so a new owner can be identified in each year for 1986 through 1998. For a plant observed in 1985, we wish to know whether an ownership change will occur for up to thirteen years in the future, while for a plant observed in 1998, we wish to know whether an ownership change occurred up to twelve years in the past. This consideration of past and future ownership changes yields a possible range of leads and lags from -13 to +12 .

The relation of past and future ownership change to productivity, size, or workforce characteristics can then be assessed, at each value of $s$, by including in the model the terms $\sum_{s=-13}^{12} \gamma_{s} O C_{i t-s}$, where $\gamma_{s}$ parameterizes the relation to ownership change at lead/lag $s$. To avoid model specification bias, each $\gamma_{s}$ is unconstrained and is estimated over the full range of $s$ from -13 to +12 . The fitted terms of $\gamma_{s}$ provide estimates of the relationship of ownership change to productivity, size, and workforce characteristics in each year.

\subsubsection{Avoiding Biases}

If just the ownership change dummies were included as regressors, the estimates would be subject to sample selection and measurement error biases. Sample selection bias would result because for large positive or negative values of $s$, the ownership change variable $O C_{i t-s}$ equals one only if the plant survived a large number of years (at least $-s+1$ years for $s<0$ or at least $s+2$ years for $s \geq 0$ ). Any characteristics of surviving plants, such as higher productivity, would thus be partially attributed to ownership change.

Measurement error bias would also result, given that ownership changes are unmeasured when they occur outside the sample time frame. For example, for $s=-13, O C_{i t-s}$ can equal one only if $t=1985$ (so $t-s=1998$ ); for other values of $t$ information about ownership changes is unavailable (since $t-s>1998$, the last year of data), causing, by definition, $O C_{i t-(13)}=0$. Similarly, for $s=-12, O C_{i t-s}$ can equal 1 only if $t \leq 1986 ; \ldots$; for $s=-1$, $O C_{i t-s}$ can equal 1 only if $t \leq 1997$; for $s=0, O C_{i t-s}$ can equal 1 only if $t \geq$ $1986 ; \ldots$; for $s=12, O C_{i t-s}$ can equal 1 only if $t=1998$. If observations are evenly dispersed across years and the probability of ownership change remains constant at $p$ over time, the expected value of $O C_{i t-s}$ would equal 
$1 / 14 p$ for $s=-13$ (as it is artificially 0 in 13 of 14 years of data), $2 / 14 p$ for $s=-12, \ldots, 13 / 14 p$ for $s=-1$ or $s=0, \ldots, 1 / 14 p$ for $s=12$. Thus, values of $O C_{i t-s}$ would constitute error-ridden indicators of ownership change, with the error greatest for the largest (absolute) values of $s$. If these ownership change measures are uncorrelated with each other and with all other regressors, the resulting coefficient estimates would be biased toward zero, with the greatest bias for estimates at large (absolute) values of $s$. If the true coefficients all equaled the same constant number $c$, the expected values of the estimates would follow a $\mathrm{U}$-shape (if $c<0$ ) or inverted $\mathrm{U}$-shape (if $c>$ $0)$. Hence, both sample selection and measurement biases could confound our analysis of the relationship between ownership change and plant performance.

Such biases can be especially severe when researchers use a balanced panel (e.g., Lichtenberg and Siegel 1987), restrict the range of $s$ (McGuckin and Nguyen 1995), or analyze pre- versus post-acquisition periods using a single coefficient for each. For example, the use of a balanced panel imparts a strong selection bias because the analysis is based only on those plants that survived throughout the sample period. Restrictions on the range of $s$ effectively constrain $\gamma_{s}$ to equal zero outside of the range, yielding possible specification error. Pre- versus post-acquisition periods effectively constrain $\gamma_{s}$ to be identical across values of $s$ and hence constitute an additional source of specification error. Moreover, none of these approaches entirely gets rid of the sample selection and measurement biases pointed out previously unless all data points are dropped from analysis if they are within $L+1$ years of the start and $L$ years of the end of the sample and the range of $s$ is constrained to $-L \leq s \leq L$.

There is a simple way to address this problem without excluding any observations. The intended comparison is between plants that experienced ownership change in year $t-s$ and those that could have but did not experience ownership change in year $t-s$ (not between plants that did experience, versus those that might have or could not have experienced, ownership change). For each $s$, we divide the observations into three types of establishments: (a) plants that did experience ownership change in year $t-s$, (b) plants that could have but did not experience ownership change in year $t-s$, and (c) plants that did not exist or those for which it is unknown whether they experienced ownership change in year $t-s$. To ensure that the coefficients $\gamma_{s}$ describe the difference between categories (a) and (b), it is sufficient to introduce into the model a dummy variable $N D_{i t-s}$ that equals 1 for any observations meeting condition (c) in year $t-s$ and 0 for all other observations. This gives rise to one additional variable for each $s$, yielding the sum $\sum_{s=-13}^{12} \delta_{1 s} N D_{i t-s}$, comparable to the ownership change term in the models. $N D_{i t-s}=1$ implies either no data about whether ownership change occurred in year $t-s$, or nonexistence of the plant in year $t-s$. These controls remove a potentially important source of bias in the estimates. 
This removal of bias may seem complex. However, it is merely a simple application of the use of dummy variables in regression models. A researcher with data on the earnings of Asian, black, and white workers could compare the mean earnings of Asians and blacks by regressing earnings on $0-1$ dummies for black and white workers and then examining the estimated coefficient on the black dummy. Were the researcher to omit the white dummy variable and include only the black dummy variable, the estimated coefficient of black would no longer yield an unbiased estimate of the black-minus-Asian earnings difference (it would be unbiased only if Asians and whites had equal expected earnings). Letting $A, B$, and $W$ denote the mean earnings of these three groups, the estimated coefficient of black converges to $B-A$ in the first regression but $B-[h A+(1-h) W]$ in the second regression, where $h$ is the proportion of Asians among all Asians plus whites in the sampled population.

The use of dummy variables is analogous here: for each $s$ replace Asians with No Change in Owner $s$ years ago, replace blacks with Change in Owner $s$ years ago, and replace whites with Don't Know whether Ownership Change Occurred $s$ years ago, and let $A, B$, and $W$ denote for these three groups the mean of the dependent variable after subtracting the effects of all other independent variables. The dummy variables used for the latter two groups are $O C_{i t-s}$ and $N D_{i t-s}$. Were a researcher to omit $N D_{i t-s}$ from a regression, the estimated coefficient of $O C_{i t-s}$ would converge not to the difference between firms with versus without ownership change, but to $B-[h A+(1-h) W]$, where $h$ is the proportion of No Change in Owner $s$ years ago cases among the total of No Change in Owner $s$ years ago cases plus Don't Know whether Ownership Change Occurred $s$ years ago cases in the sampled population. Indeed, in simulations we have found substantial bias without the $N D_{i t-s}$ controls, but no bias once they are introduced.

To reduce another possible bias, caused by cross-industry, cross-year, or cross-plant-age differences in both the probability of acquisition and the dependent variable (or productivity), additional controls are used. Fixed effect dummies are included in all analyses for each year, four-digit industry (according to 1969 Swedish SICs), and plant age. ${ }^{7}$ In addition, production function parameters are each allowed to differ by industry, effectively, by including interaction terms that equal industry-specific dummies $\left(I_{k i t}=\right.$ 1 if plant $i$ 's primary industry is equal to $k$ or $I_{k i t}=0$ otherwise) times each

7. Industries must be defined according to 1969 industries because only in the later years of the sample have plants been classified according to more recent industry definitions. Another limitation of the data is that they do not include plant ages, so plants are classified according to their minimum age $(1+, 2+, \ldots)$ if they existed in 1985 or their actual age if they entered after 1985. Fortunately, the employee-level data file indicated (for nearly all plants) whether each plant existed in each year, even if it was not present in the plant-level data; these additional data therefore allowed identification of plant age without sample selection in years 1985 to 1998. 
production function parameter. ${ }^{8}$ Use of these controls implies that the relations of ownership change are studied largely for plants of comparable industry and age at a comparable date.

\subsubsection{Endogeneity and Descriptive Estimation}

It is common in the estimation of production functions to use instrumental variables to ensure consistent parameter estimates despite possible endogeneity. In our context, ownership change may be endogenous, since some theories conjecture that the sale of a plant or firm may be more likely when it has relatively low productivity. Just as instrumental variables methods can be used to estimate a supply or demand equation rather than a mixture of the two, such techniques could be used in an analysis of the consequences of ownership change.

In this chapter, however, our aim is not to estimate either causes or consequences, but merely to describe patterns experienced on average before and after plants undergo ownership change. We focus on describing trends in several key variables before and after ownership change. ${ }^{9}$

\subsection{Empirical Results}

\subsubsection{Descriptive Statistics for Plant-Level Variables}

Table 11.7 contains descriptive statistics for key variables used in the econometric analysis, presented separately for plants that experienced an ownership change and for those that did not. Plants involved in these transactions tend to be larger by about 60 percent. ${ }^{10} \mathrm{On}$ average, they employed slightly smaller percentages of female workers and workers with at least a college education, and slightly more non-Swedish employees than plants that did not experience an ownership change.

\subsubsection{Productivity, Output, and Employment as Related to Ownership Change}

We now consider changes in productivity and plant size associated with ownership change. Table 11.8 presents OLS estimates of four equations: labor productivity, total factor productivity, output, and employment. The equations we estimate are the following.

8. We also experimented with including detailed geographic region dummies in the TFP equation, and found that their inclusion had almost no effect on our results.

9. The focus on observed empirical patterns matches the descriptive focus of the NBER conference for which this paper was developed, and accords with the wishes of the conference organizers.

10. The 60 percent greater size of plants experiencing ownership change than those not experiencing ownership change can be computed as $\exp (9.98-9.51)=1.6$. 
Table 11.7 Means and standard deviations of production function variables and worker characteristics

\begin{tabular}{lccc}
\hline Variable & All plants & $\begin{array}{c}\text { Plants that } \\
\text { experience an } \\
\text { ownership change }\end{array}$ & $\begin{array}{c}\text { Plants that do } \\
\text { not experience an } \\
\text { ownership change }\end{array}$ \\
\hline Log gross output & 9.68 & 9.98 & 9.51 \\
Log real value of plant and & $(1.52)$ & $(1.55)$ & $(1.51)$ \\
machinery capital stock & 9.21 & 9.60 & 9.01 \\
Log plant employment & $(1.49)$ & $(1.41)$ & $(1.48)$ \\
& 3.36 & 3.67 & 3.18 \\
Log materials & $(1.21)$ & $(1.22)$ & $(1.17)$ \\
& 8.80 & 9.18 & 8.59 \\
Average age of employees & $(1.82)$ & $(1.75)$ & $(1.82)$ \\
& 39.49 & 39.57 & 39.45 \\
Percentage of female employees & $(5.36)$ & $(4.95)$ & $(5.56)$ \\
Percentage of non-Swedish & 25.77 & 25.18 & 26.08 \\
employees & $(21.64)$ & $(20.61)$ & $(22.17)$ \\
Percentage of employees with & 9.24 & 9.62 & 9.04 \\
at least a college education & $(11.49)$ & $(11.17)$ & $(11.66)$ \\
Log earnings & 2.81 & 2.45 & 3.00 \\
& $(7.11)$ & $(5.85)$ & $(7.68)$ \\
& 11.86 & 11.85 & 11.86 \\
& $(0.37)$ & $(0.36)$ & $(0.38)$ \\
\hline
\end{tabular}

Note: Standard deviations are in parentheses.

Labor Productivity:

(14) $\ln \left(Q_{i j t}\right)=\alpha_{j t}+\beta_{1 j} \ln \left(L_{i j t}\right)+\sum_{s=-13}^{12} \gamma_{s} O C_{i j t-s}+\sum_{s=-13}^{12} \delta_{s} N D_{i j t-s}$

$$
+ \text { Age Dummies + Industry Dummies }+ \text { Time Dummies }+\varepsilon_{i j t}
$$

Total Factor Productivity:

$$
\begin{aligned}
\ln \left(Q_{i j t}\right)= & \alpha_{j t}+\beta_{1 j} \ln \left(L_{i j t}\right)+\beta_{2 j} \ln \left(K_{i j t}\right)+\beta_{3 j} \ln \left(M_{i j t}\right) \\
& +\sum_{s=-13}^{12} \gamma_{s} O C_{i j t-s}+\sum_{s=-13}^{12} \delta_{s} N D_{i j t-s}+\text { Age Dummies } \\
& + \text { Industry Dummies }+ \text { Time Dummies }+\varepsilon_{i j t}
\end{aligned}
$$

Output or Employment:

$$
\begin{aligned}
y_{i j t}= & \alpha_{j t}+\sum_{s=-13}^{12} \gamma_{s} O C_{i j t-s}+\sum_{s=-13}^{12} \delta_{s} N D_{i j t-s}+\text { Age Dummies } \\
& + \text { Industry Dummies }+ \text { Time Dummies }+\varepsilon_{i j t}
\end{aligned}
$$


Table 11.8 Parameter estimates from labor productivity, total factor productivity, output, and employment regressions for all ownership changes

\begin{tabular}{|c|c|c|c|c|}
\hline Coefficient on: & $\begin{array}{c}\text { Labor } \\
\text { productivity }\end{array}$ & $\begin{array}{c}\text { TFP } \\
\text { (Cobb-Douglas) }\end{array}$ & Output & Employment \\
\hline Labor $^{\mathrm{a}}$ & $\begin{array}{l}1.054 * * * * \\
(0.014)\end{array}$ & $\begin{array}{l}.375^{* * * * *} \\
(.014)\end{array}$ & - & - \\
\hline Capital $^{\mathrm{a}}$ & - & $\begin{array}{l}.270 * * * * \\
(.018)\end{array}$ & - & - \\
\hline Materials $^{\mathrm{a}}$ & $\begin{array}{l}.347^{* * * * *} \\
-\end{array}$ & $(.014)$ & - & - \\
\hline $\mathrm{OC}_{\mathrm{t}+13}$ & $\begin{array}{l}-0.52 \\
(.035)\end{array}$ & - & $\begin{array}{l}.092 \\
(.093)\end{array}$ & $\begin{array}{l}.162^{*} \\
(.085)\end{array}$ \\
\hline $\mathrm{OC}_{\mathrm{t}+12}$ & $\begin{array}{l}-.042^{*} \\
(.025)\end{array}$ & - & $\begin{array}{l}.020 \\
(.060)\end{array}$ & $\begin{array}{l}.058 \\
(.052)\end{array}$ \\
\hline $\mathrm{OC}_{\mathrm{t}+11}$ & $\begin{array}{l}-.010 \\
(.020)\end{array}$ & - & $\begin{array}{l}.049 \\
(.045)\end{array}$ & $\begin{array}{l}.055 \\
(.040)\end{array}$ \\
\hline $\mathrm{OC}_{\mathrm{t}+10}$ & $\begin{array}{l}-.027^{*} \\
(.017)\end{array}$ & - & $\begin{array}{l}.060 \\
(.039)\end{array}$ & $\begin{array}{l}.083^{* *} \\
(.035)\end{array}$ \\
\hline $\mathrm{OC}_{\mathrm{t}+9}$ & $\begin{array}{l}-.036^{* *} \\
(.015)\end{array}$ & $\begin{array}{l}.009 \\
(.018)\end{array}$ & $\begin{array}{l}.114^{* * * * *} \\
(.035)\end{array}$ & $\begin{array}{l}.142^{* * * * *} \\
(.032)\end{array}$ \\
\hline $\mathrm{OC}_{\mathrm{t}+8}$ & $\begin{array}{l}-.035^{* * * * *} \\
(.013)\end{array}$ & $\begin{array}{l}.012 \\
(.011)\end{array}$ & $\begin{array}{l}.136 * * * * \\
(.029)\end{array}$ & $\begin{array}{l}.163^{* * * * *} \\
(.026)\end{array}$ \\
\hline $\mathrm{OC}_{\mathrm{t}+7}$ & $\begin{array}{l}-.039^{* * * * *} \\
(.011)\end{array}$ & $\begin{array}{l}.011 \\
(.011)\end{array}$ & $\begin{array}{l}.162^{* * * * *} \\
(.026)\end{array}$ & $\begin{array}{l}.191^{* * * * *} \\
(.023)\end{array}$ \\
\hline $\mathrm{OC}_{\mathrm{t}+6}$ & $\begin{array}{l}-.041 \text { ***** } \\
(.010)\end{array}$ & $\begin{array}{l}-.018^{* *} \\
(.008)\end{array}$ & $\begin{array}{l}.186^{* * * * *} \\
(.023)\end{array}$ & $\begin{array}{l}.216^{* * * * *} \\
(.020)\end{array}$ \\
\hline $\mathrm{OC}_{\mathrm{t}+5}$ & $\begin{array}{l}-.041^{* * * * *} \\
(.010)\end{array}$ & $\begin{array}{l}-.031^{* * * * *} \\
(.008)\end{array}$ & $\begin{array}{l}.205^{* * * *} \\
(.022)\end{array}$ & $\begin{array}{l}.232^{* * * * *} \\
(.019)\end{array}$ \\
\hline $\mathrm{OC}_{\mathrm{t}+4}$ & $\begin{array}{l}-.041 * * * * \\
(.009)\end{array}$ & $\begin{array}{l}-.028 * * * * \\
(.006)\end{array}$ & $\begin{array}{l}.179 * * * * \\
(.020)\end{array}$ & $\begin{array}{l}.208^{* * * * *} \\
(.017)\end{array}$ \\
\hline $\mathrm{OC}_{\mathrm{t}+3}$ & $\begin{array}{l}-.042^{* * * * *} \\
(.009)\end{array}$ & $\begin{array}{l}-.039 * * * * \\
(.006)\end{array}$ & $\begin{array}{l}.178^{* * * * *} \\
(.019)\end{array}$ & $\begin{array}{l}.208^{* * * * *} \\
(.016)\end{array}$ \\
\hline $\mathrm{OC}_{\mathrm{t}+2}$ & $\begin{array}{l}-.035^{* * * * *} \\
(.008)\end{array}$ & $\begin{array}{l}-.036^{* * * * *} \\
(.005)\end{array}$ & $\begin{array}{l}.179 * * * * \\
(.018)\end{array}$ & $\begin{array}{l}.202^{* * * * *} \\
(.015)\end{array}$ \\
\hline $\mathrm{OC}_{\mathrm{t}+1}$ & $\begin{array}{l}-.050^{* * * * *} \\
(.009)\end{array}$ & $\begin{array}{l}-.056^{* * * * *} \\
(.006)\end{array}$ & $\begin{array}{l}.153^{* * * * *} \\
(.018)\end{array}$ & $\begin{array}{l}.195^{* * * * *} \\
(.015)\end{array}$ \\
\hline $\mathrm{OC}_{\mathrm{t}+0}$ & $\begin{array}{l}-.022^{* * *} \\
(.008)\end{array}$ & $\begin{array}{l}-.066^{* * * * *} \\
(.006)\end{array}$ & $\begin{array}{l}-.001 \\
(.017)\end{array}$ & $\begin{array}{l}.022^{* * * * *} \\
(.015)\end{array}$ \\
\hline $\mathrm{OC}_{\mathrm{t}-1}$ & $\begin{array}{l}-.009 \\
(.008)\end{array}$ & $\begin{array}{l}-.032 \text { ***** } \\
(.005)\end{array}$ & $\begin{array}{l}.082 * * * * \\
(.018)\end{array}$ & $\begin{array}{l}.086^{* * * * *} \\
(.015)\end{array}$ \\
\hline $\mathrm{OC}_{\mathrm{t}-2}$ & $\begin{array}{l}-.004 \\
(.009)\end{array}$ & $\begin{array}{l}-.024 * * * * \\
(.005)\end{array}$ & $\begin{array}{l}.092 * * * * \\
(.019)\end{array}$ & $\begin{array}{l}.087 * * * * \\
(.016)\end{array}$ \\
\hline $\mathrm{OC}_{\mathrm{t}-3}$ & $\begin{array}{c}.002 \\
(.010)\end{array}$ & $\begin{array}{l}-.013^{* * *} \\
(.006)\end{array}$ & $\begin{array}{l}.101 * * * * \\
(.021)\end{array}$ & $\begin{array}{l}.092 * * * * \\
(.018)\end{array}$ \\
\hline $\mathrm{OC}_{\mathrm{t}-4}$ & $\begin{array}{l}.002 \\
(.010)\end{array}$ & $\begin{array}{l}-.020^{* * * *} \\
(.006)\end{array}$ & $\begin{array}{l}.095^{* * * * *} \\
(.023)\end{array}$ & $\begin{array}{l}.088^{* * * * *} \\
(.019)\end{array}$ \\
\hline $\mathrm{OC}_{\mathrm{t}-5}$ & $\begin{array}{l}.005 \\
(.011)\end{array}$ & $\begin{array}{l}-.014 * * \\
(.007)\end{array}$ & $\begin{array}{l}.097 * * * * \\
(.025)\end{array}$ & $\begin{array}{l}.090^{* * * * *} \\
(.021)\end{array}$ \\
\hline $\mathrm{OC}_{\mathrm{t}-6}$ & $\begin{array}{l}.019 \\
(.012)\end{array}$ & $\begin{array}{l}-.006 \\
(.007)\end{array}$ & $\begin{array}{l}.142^{* * * * *} \\
(.028)\end{array}$ & $\begin{array}{l}.120^{* * * * *} \\
(.024) \\
\text { (continued) }\end{array}$ \\
\hline
\end{tabular}


Table 11.8 (continued)

\begin{tabular}{lcccc}
\hline Coefficient on: & $\begin{array}{c}\text { Labor } \\
\text { productivity }\end{array}$ & $\begin{array}{c}\text { TFP } \\
\text { (Cobb-Douglas) }\end{array}$ & Output & Employment \\
\hline $\mathrm{OC}_{\mathrm{t}-7}$ & $.043^{* * *}$ & $.017^{* *}$ & $.187^{* * * *}$ & $.140^{* * * * *}$ \\
& $(.014)$ & $(.008)$ & $(.033)$ & $(.027)$ \\
$\mathrm{OC}_{\mathrm{t}-8}$ & $.030^{*}$ & .009 & $.159^{* * * *}$ & $.119^{* * * *}$ \\
& $(.013)$ & $(.011)$ & $(.037)$ & $(.030)$ \\
$\mathrm{OC}_{\mathrm{t}-9}$ & $.037^{* *}$ & $.021^{*}$ & $.139^{* * * *}$ & $.096^{* * * *}$ \\
& $(.018)$ & $(.012)$ & $(.041)$ & $(.034)$ \\
$\mathrm{OC}_{\mathrm{t}-10}$ & $.040^{*}$ & $.024^{*}$ & $.175^{* * * *}$ & $.124^{* * * *}$ \\
& $(.022)$ & $(.014)$ & $(.050)$ & $(.041)$ \\
OC $_{\mathrm{t}-11}$ & $.061^{* *}$ & $.046^{* *}$ & $.201^{* * * *}$ & $.121^{* * *}$ \\
& $(.030)$ & $(.021)$ & $(.069)$ & $(.057)$ \\
OC $_{\mathrm{t}-12}$ & .024 & .028 & $.171^{* * * *}$ & .104 \\
& $(.054)$ & $(.038)$ & $(.108)$ & $(.091)$ \\
"No-data" dummies & Yes & Yes & Yes & Yes \\
Industry dummies & Yes & Yes & Yes & Yes \\
Year dummies & Yes & Yes & Yes & Yes \\
Age dummies & Yes & Yes & Yes & Yes \\
Intercept & $6.150^{* * * *}$ & $2.084^{* * * *}$ & $10.610^{* * * *}$ & $4.049^{* * * *}$ \\
& $(0.053)$ & $(.143)$ & $(.059)$ & $(.049)$ \\
$\mathrm{R}^{2}$ & 0.859 & 0.960 & 0.358 & 0.301 \\
Number of plants & 18,495 & 15,946 & 18,513 & 18,962 \\
Number of observations & 124,381 & 82,307 & 124,441 & 125,416 \\
\hline
\end{tabular}

Note: Standard errors in parentheses. Significance levels are two-tailed using robust standard errors, allowing for correlated ("clustered") errors within plants.

${ }^{a}$ Weighted means of industry-specific coefficients at the detailed (four-digit SIC) industry level.

**** Indicates significance at the 0.1 percent level.

$* * *$ Indicates significance at the 1 percent level.

** Indicates significance at the 5 percent level.

* Indicates significance at the 10 percent level.

where $L_{i j t}, K_{i j t}$, and $M_{i j t}$ are labor, capital, and materials for plant $i$ in industry $j$ at year $t, O C_{i j t-s}$ and $N D_{i j t-s}$ are the ownership change and no-data dummy variables described earlier, and $y_{i j t}$ is output or employment for plant $i$ in industry $j$ at year $t{ }^{11}$ Recall that each regression is estimated with detailed industry level (four-digit SIC) fixed effects. Thus, the coefficients on the nonownership change variables (labor, capital, and materials) are weighted means of industry-specific coefficients.

The coefficients on labor, capital, and materials in the two productivity

11. The equations deliberately do not include plant fixed effects, only industry fixed effects, because including plant fixed effects would make it impossible to observe whether plants that experience ownership change tend to have persistently low or high productivity or, indeed, to know how these plants compare to their industry (and age and time) averages at all - all patterns that are important to be able to detect. 
models appear to be plausible. They are reasonably close to their respective factor shares and strongly suggestive of constant returns to scale. The total factor productivity (TFP) equation is estimated for a restricted sample of plants and years, because the capital measure is only available from 1989 onward and, in those years, for 92.3 percent of plants.

Next, we focus our attention on the coefficients on the ownership change dummies in table 11.8. For example, the value -.042 for the estimated coefficient of $O C_{-1}$ in the labor productivity equation signifies that plants experiencing an ownership change one year hence were 4.2 percent less productive, on average, than comparable establishments that did not change owners. Note that while the relative performance of plants changing owners was significantly worse before the transaction, relative efficiency appears to have improved after the ownership change, as these establishments converged to the average level of industry performance. The LP estimates indicate lower than average productivity before ownership change, followed by a rapid increase to the industry norm, and ultimately, higher productivity following the ownership change. The TFP estimates indicate productivity steadily deteriorating to a low of nearly 6 percent below average, followed by a steady return to average and higher productivity after the ownership change. The decline in TFP, but not LP, in the five years preceding ownership change implies that while labor was used inefficiently in these plants, it was in the application of equipment and materials that they experienced a gradual efficiency decline. ${ }^{12}$

The output and employment results, which are presented in the last two columns of table 11.8, help explain the productivity increase. Plants that changed owners apparently had higher output and employment than comparable plants both before and after ownership change. They reduced both output and employment after an ownership change. ${ }^{13}$ However, employment declined at a faster rate than output, which resulted in a productivity increase.

In table 11.9, we present averages of the coefficients on the ownership change dummies in the LP, TFP, output, and employment equations for five years before and five years after the transaction (we exclude year zero, which is the year of the acquisition). In the third row of each panel, we

12. The TFP results are based on a subsample of observations, since capital stock measures are unavailable before 1989. However, this is not the source of the difference between the LP and TFP results. Estimating the LP equation using the same subsample of observations as for the TFP regression yields nearly identical results to those reported for LP in the chapter.

13. Although the change in output could result either from a decision on the part of the new owners or a firm-specific shock that triggers ownership change, there is some evidence that the output reductions may in fact result from the decisions of the new management. First, similar declines in output do not coincide with the gradual reduction in productivity that precedes ownership change. Second, the same decline in output and employment are apparent after adding industry-year interactions to the model using four-digit SIC codes, thereby controlling for possible industry-specific demand shocks. This leaves open the possibility of other shocks that lead to ownership change and also to downsizing. 


\begin{tabular}{|c|c|c|c|c|}
\hline Period & LP & TFP & Output & Employment \\
\hline \multicolumn{5}{|c|}{ All ownership changes } \\
\hline Pre-ownership change & $-0.042^{* * * *}$ & $-0.038^{* * *}$ & $0.179 * * * *$ & $0.209 * * * *$ \\
\hline Post-ownership change & -0.001 & $-0.021 * * *$ & $0.093 * * * *$ & $0.089 * * * *$ \\
\hline Post-pre & $0.041 * * * *$ & $0.017 * * *$ & $-0.086^{* * * *}$ & $-0.120 * * * *$ \\
\hline \multicolumn{5}{|c|}{ Full acquisitions } \\
\hline Pre-ownership change & $-0.055^{* * * *}$ & $-0.038 * * * *$ & $0.061 * * *$ & $0.111 * * * *$ \\
\hline Post-ownership change & -0.007 & $-0.024 * * * *$ & $-0.055^{* * *}$ & $-0.046^{* * *}$ \\
\hline Post-pre & $0.047 * * * *$ & $0.014 * *$ & $-0.116 * * * *$ & $-0.156^{* * * *}$ \\
\hline \multicolumn{5}{|c|}{ Partial acquisitions } \\
\hline Pre-ownership change & 0.011 & $-0.037 * *$ & $0.633 * * * *$ & $0.584 * * * *$ \\
\hline Post-ownership change & 0.019 & -0.011 & $0.556^{* * * *}$ & $0.510 * * * *$ \\
\hline Post-pre & 0.008 & $0.026^{*}$ & $-0.076 * *$ & $-0.073^{* *}$ \\
\hline \multicolumn{5}{|c|}{ Full divestitures } \\
\hline Pre-ownership change & $-0.052^{* * * *}$ & $-0.039 * * * *$ & $0.092 * * * *$ & $0.137 * * * *$ \\
\hline Post-ownership change & -0.005 & $-0.022 * * * *$ & -0.012 & -0.007 \\
\hline Post-pre & $0.047 * * * *$ & $0.017^{* * *}$ & $-0.104 * * * *$ & $-0.144 * * * *$ \\
\hline \multicolumn{5}{|c|}{ Partial divestitures } \\
\hline Pre-ownership change & 0.019 & $-0.030 *$ & $0.684 * * * *$ & $0.628 * * * *$ \\
\hline Post-ownership change & 0.018 & -0.014 & $0.594^{* * * *}$ & $0.551 * * * *$ \\
\hline Post-pre & -0.001 & $0.015^{*}$ & $-0.090 * *$ & $-0.077 * *$ \\
\hline \multicolumn{5}{|c|}{ Related acquisitions } \\
\hline Pre-ownership change & 0.005 & $-0.043^{* * * *}$ & $0.429 * * * *$ & $0.402 * * * *$ \\
\hline Post-ownership change & 0.021 & -0.009 & $0.363 * * * *$ & $0.324 * * * *$ \\
\hline Post-pre & 0.015 & $0.034^{* *}$ & $-0.066^{*}$ & $-0.079 * *$ \\
\hline \multicolumn{5}{|c|}{ Unrelated acquisitions } \\
\hline Pre-ownership change & -0.013 & $-0.034 * *$ & $0.345^{* * * *}$ & $0.346^{* * * *}$ \\
\hline Post-ownership change & 0.020 & -0.010 & $0.234 * * * *$ & $0.208 * * * *$ \\
\hline Post-pre & $0.033^{* *}$ & 0.024 & $-0.111^{*}$ & $-0.138^{* * *}$ \\
\hline \multicolumn{5}{|c|}{ Change in ownership involving a single firm } \\
\hline Pre-ownership change & $-0.059^{* * * *}$ & $-0.037 * * *$ & $0.087 * * *$ & $0.137 * * * *$ \\
\hline Post-ownership change & -0.007 & $-0.024 * * *$ & 0.014 & 0.020 \\
\hline Post-pre & $0.052^{* * * *}$ & $0.013^{*}$ & $-0.075^{* * * *}$ & $-0.118 * * * *$ \\
\hline
\end{tabular}

Notes: Pre-ownership change is average 5 years before; post-ownership change is average 5 years after. Significance levels are two-tailed using robust standard errors, allowing for correlated ("clustered") errors within plants.

**** Indicates significance at the 0.1 percent level.

*** Indicates significance at the 1 percent level.

** Indicates significance at the 5 percent level.

* Indicates significance at the 10 percent level. 
report the growth in the average coefficient from the five years before to the five years after ownership change, and we formally test whether the postversus pre-ownership change effects are statistically significant. Our findings are also presented separately in table 11.9 for various types of ownership change: full acquisitions and partial acquisitions, full divestitures and partial divestitures, related acquisitions, unrelated acquisitions, and changes in ownership involving a single firm.

The "post-pre" results in the first panel of table 11.9 confirm our earlier finding that plants involved in an ownership change became more productive after the transaction. From the five years before to the five years after ownership change, LP is estimated to have increased by 4.1 percent ( $p<$ $.001)$ and TFP by 1.7 percent $(p<.01)$. We also find that output and employment were reduced after ownership change, with employment declining more than output. Output is estimated to have declined by 8.6 percent $(p<.001)$ from the pre- to post-ownership change five-year periods, and employment is estimated to have decreased by 12.0 percent $(p<.001)$.

The growth in LP is estimated to have been much higher for full acquisitions and divestitures than for partial acquisitions and divestitures (panels 2 through 5 of table 11.9). In full-firm acquisitions and divestitures both, labor productivity grew an estimated 4.7 percent between the two five-year periods (both $p<.001$ ). In contrast, partial acquisitions were associated with only 0.8 percent growth in LP, while partial divestitures were associated with a decrease of 0.1 percent in LP (both changes are insignificantly different from zero). The difference may stem from the fact that plants acquired through partial acquisition and divestiture had higher labor productivity to begin with, 1.1 percent above the norm for partial acquisitions and 1.9 percent above the norm for partial divestitures, versus labor productivity averaging 5.5 percent below the industry norm for full acquisitions and 5.2 percent below the industry norm for partial divestitures. ${ }^{14}$

Growth in TFP was much more similar across full versus partial acquisitions and divestitures. Partial acquisitions are estimated to have experienced slightly higher (2.6 percent) TFP growth between the two five-year periods than either full acquisitions (1.4 percent) or any type of divestiture (1.5 percent to 1.7 percent), but the difference is not statistically significant. All types of acquisitions and divestitures involved plants whose TFP was about 3.0 percent to 3.9 percent below the norm before ownership change.

Labor Productivity (LP) grew more in the aftermath of unrelated acquisitions, as opposed to related acquisitions, and even more in ownership

14. These differences pre-ownership change might stem from higher labor productivity in larger plants or from cherry-picking by acquiring firms that purchase only some of a firm's plants. 
changes that did not involve a second (manufacturing) firm. Among these three types of ownership change, the increase in labor productivity was negatively related to initial productivity: single-firm ownership changes increased their LP an estimated 5.2 percent $(p<.001)$ from 5.9 percent below the norm to 0.7 percent below the norm, while unrelated acquisitions saw LP increase an estimated 3.3 percent $(p<.05)$ from 1.3 percent below the norm to 2.0 percent above the norm, and related acquisitions saw LP increase only an estimated 1.5 percent (statistically insignificant) from 0.5 percent above the norm to 2.1 percent above the norm. Total Factor Productivity (TFP) growth was substantial and significant, but was greatest for related acquisitions, with 3.4 percent growth $(p<.05)$ from an initial base 4.3 percent below the norm, whereas the unrelated and single-firm ownership changes, respectively, experienced only 2.4 percent (insignificant) and 1.3 percent $(p<.10)$ TFP growth from initial bases 3.4 percent and 3.7 percent below the norm. The finding that unrelated acquisitions enhanced plant productivity is consistent with U.S. evidence presented in Maksimovic and Phillips (2001) and Schoar (2002).

The decline in output, and especially employment, was greatest in the aftermath of full acquisitions and divestitures, for which output declined 11.6 percent $(p<.001)$ and 10.4 percent $(p<.001)$, respectively, and employment declined 15.6 percent $(p<.001)$ and 14.4 percent $(p<.001)$ respectively. In contrast, partial acquisitions and divestitures respectively experienced an estimated 7.6 percent $(p<.05)$ and 9.0 percent $(p<.05)$ decline in output and 7.3 percent $(p<.05)$ and 7.7 percent $(p<.05)$ decline in employment. Partial acquisitions and divestitures tended to involve plants that were substantially larger to begin with, starting larger than the norm by an estimated 63.3 percent and 68.4 percent, respectively, versus only 6.1 percent and 9.2 percent for full acquisitions and divestitures. The declines in output and employment are estimated to have been greater for unrelated acquisitions than for related acquisitions, but there is no statistically significant difference between the related and unrelated (and singlefirm) acquisitions.

Both the annual coefficient estimates and the five-year means for all ownership changes combined are shown graphically in figures 11.1 through 11.4. These graphs make it easy to visualize the relation of the four variables to ownership change, and moreover, clarify annual patterns that are not evident in the five-year means. The horizontal axis in each graph spans a fifteen-year period, from seven years before ownership change to seven years after ownership change. The vertical axis corresponds to the values of the estimated coefficients, and hence to the relation of ownership change to productivity, output, or employment at a given time relative to the year of ownership change. The curve drawn across the diagram shows the annually changing values of productivity relative to the industry (and age and year) norm. For each coefficient estimate, its 95 percent confidence 


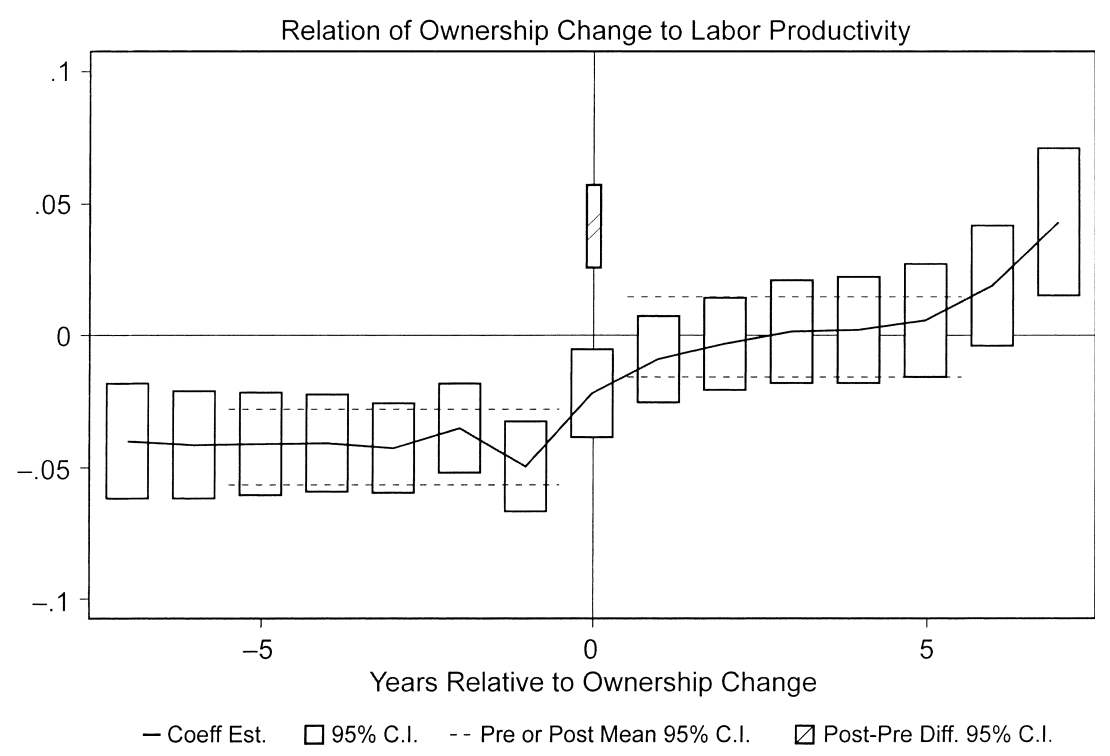

Fig. 11.1 Graphs of the coefficients on the ownership change dummies in the LP equation

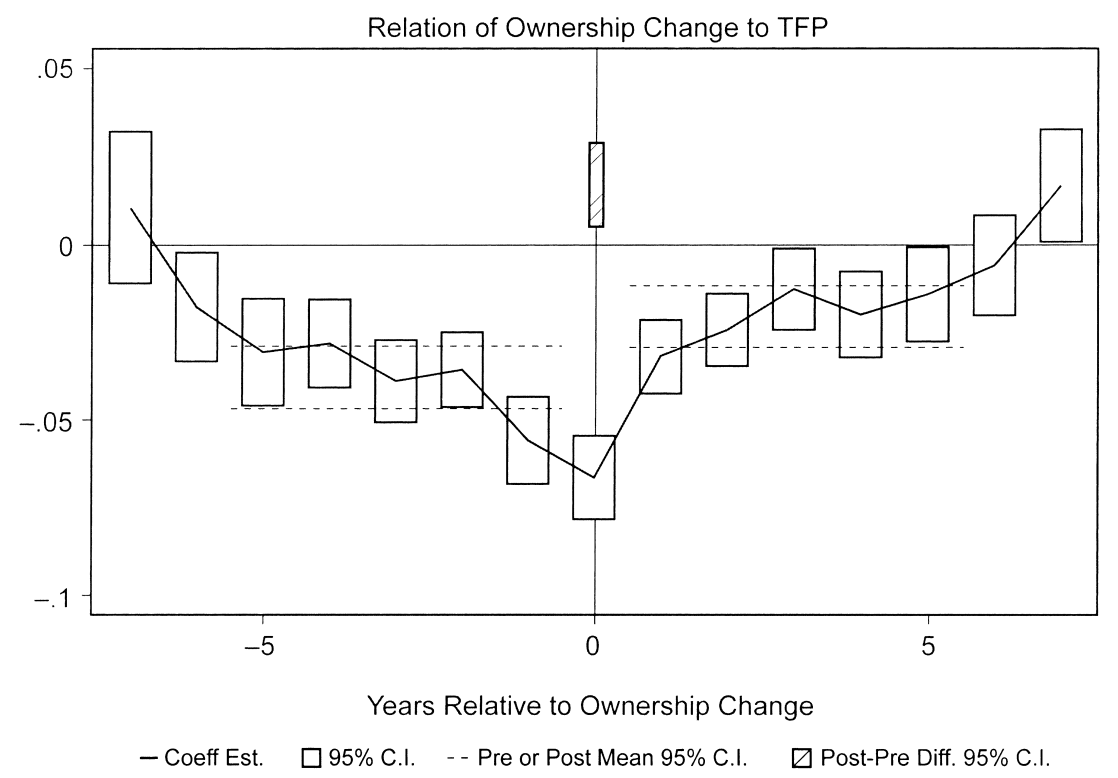

Fig. 11.2 Graphs of the coefficients on the ownership change dummies in the TFP equation 


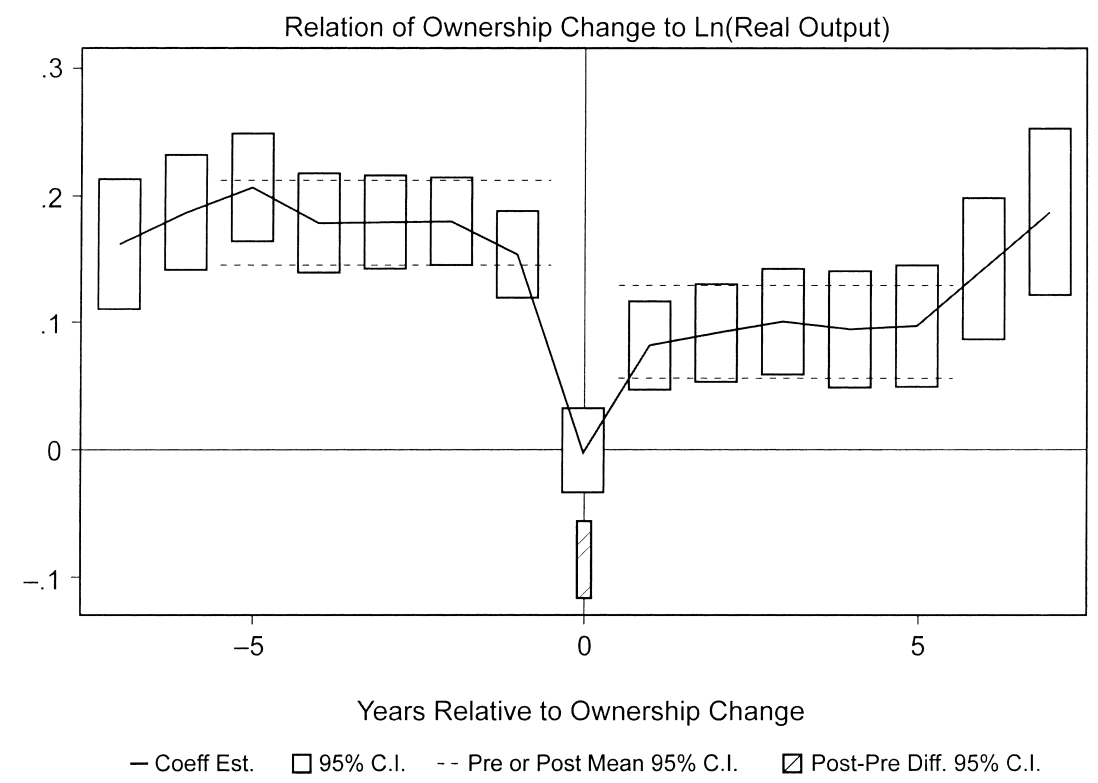

Fig. 11.3 Graph of the coefficients on the ownership change dummies in the output equation

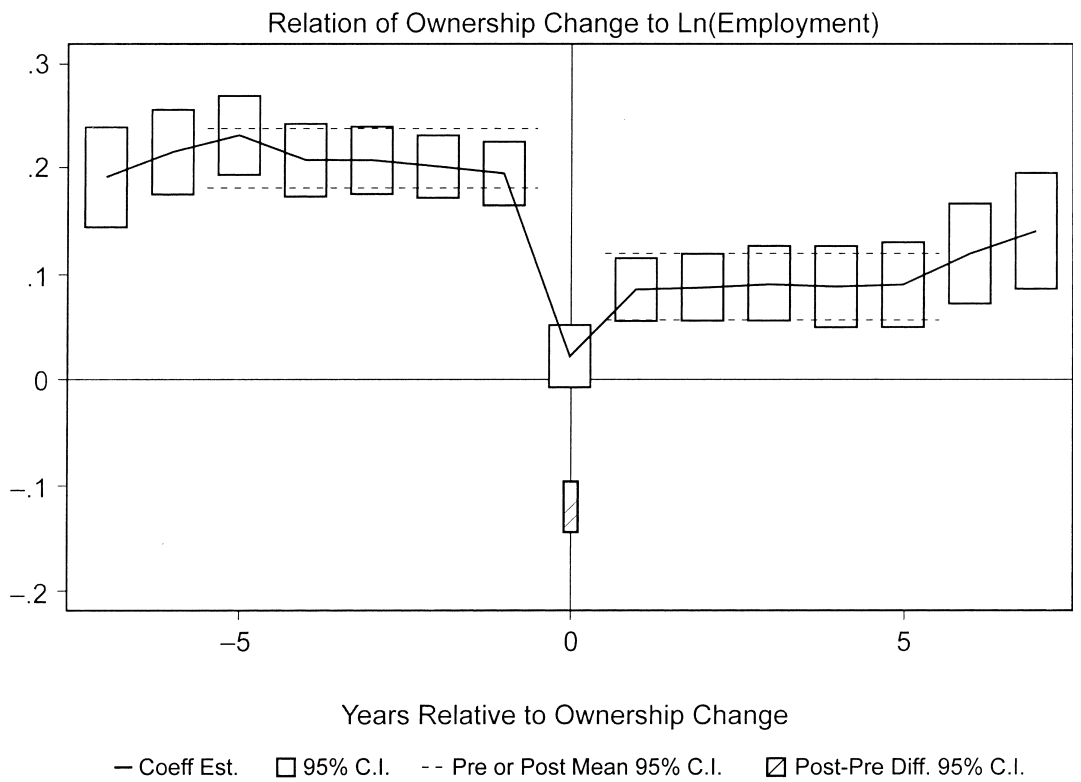

Fig. 11.4 Graph of the coefficients on the ownership change dummies in the employment equation 
band clarifies the range of error in the estimates. Dashed lines in the five years pre- and post-ownership change indicate 95 percent confidence bands for means before and after ownership change, and a 95 percent band drawn at year zero pertains to the change between the five-year periods pre- to post-ownership change.

The graphs demonstrate that five-year averages can mask important dynamics related to the time of ownership change. For labor productivity, the five-year means provide an accurate summary, but for TFP, they hide a substantial and statistically significant decline in productivity up to the time of ownership change, followed by substantial growth in productivity that begins immediately after the year of ownership change. The pattern indeed looks as if typical plants had been losing TFP relative to the norm at a pace of about 1 percent per year before ownership change, with the new owners apparently managing to enhance productivity by about 4 percent within one year after ownership change and continuing to enhance productivity by about 0.5 percent per year thereafter.

The graphs for real output and employment also indicate substantial disruptions in the year of ownership change, with plants formerly about 15 percent above the norm in output and 20 percent above the norm in employment suddenly falling to levels near their industry (and age and year) means. Under the new ownership, output (especially) and employment (somewhat) then grew immediately in the year following ownership change, with very slow increases in subsequent years.

\subsubsection{Labor Force Characteristics as Related to Ownership Change}

In table 11.10, we present similar results for six labor-related dependent variables: the average age of employees at the plant, average experience, the percentage of female employees, the percentage of non-Swedish employees,

Table 11.10 Estimated effects of ownership change on age, experience, $\%$ female, $\%$ non-Swedish, $\%$ college-educated, and earnings

\begin{tabular}{lllcccc}
\hline \multirow{2}{*}{ Period } & \multicolumn{1}{c}{ Age } & Experience & Female & Non-Swedish & $\begin{array}{c}\% \text { College- } \\
\text { educated }\end{array}$ & Earnings \\
\hline Pre-ownership change & 0.053 & 0.046 & $0.766^{* * * * *}$ & $0.360^{* *}$ & -0.051 & $-0.009^{* * * *}$ \\
Post-ownership change & $0.213^{* * * * *}$ & $0.213^{* * * *}$ & 0.117 & 0.245 & 0.126 & $0.004^{*}$ \\
Post-pre & $0.160^{* *}$ & $0.167^{* * *}$ & $-0.649 * * *$ & -0.114 & $0.177^{* *}$ & $0.013^{* * * *}$ \\
\hline
\end{tabular}

Notes: Pre-ownership change is average 5 years before; post-ownership change is average 5 years after. Significance levels are two-tailed using robust standard errors, allowing for correlated ("clustered") errors within plants.

$* * * *$ Indicates significance at the 0.1 percent level.

*** Indicates significance at the 1 percent level.

** Indicates significance at the 5 percent level.

* Indicates significance at the 10 percent level. 
the percentage of college-educated workers, and earnings. As before, the table includes estimates for the various types of ownership change. Figures 11.5 through 11.10 present graphical representations of the annual coefficient estimates for all ownership changes.

The findings in table 11.10 imply that plants involved in ownership change experienced estimated increases in average employee age by 0.16 year or about two months of age $(p<.05)$, in experience by 0.17 year $(p<.01)$, and in the percentage of employees with a college education by (an absolute amount of) 0.18 percent $(p<.05)$. The age and experience results suggest some tendency for newer workers to be laid off or leave more often than older workers. The education result suggests that ownership change led to a reduction in the demand for less-educated workers. We also find that ownership change resulted in an increase in employees' mean earnings (as always, relative to the industry and plant age and year norm) by 1.3 percent $(p<.001)$ and a decline in the percentage of female workers by (an absolute amount of) 0.65 percent $(p<.01)$. The increase in earnings is consistent with more experienced employees remaining, while newer workers left, since (as the employee-level data confirm) the older and more experienced workers received higher earnings. The decline in the percentage of female workers might have been related to women workers often having shorter

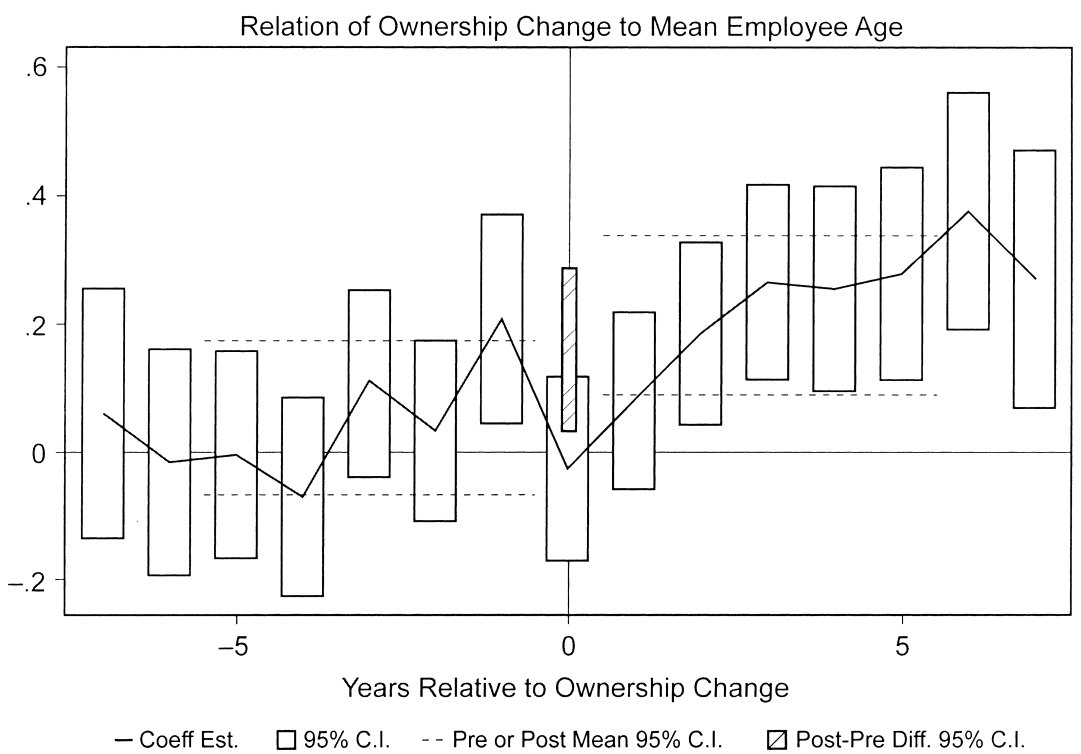

Fig. 11.5 Graph of the coefficients on the ownership change dummies in the mean employee age equation 


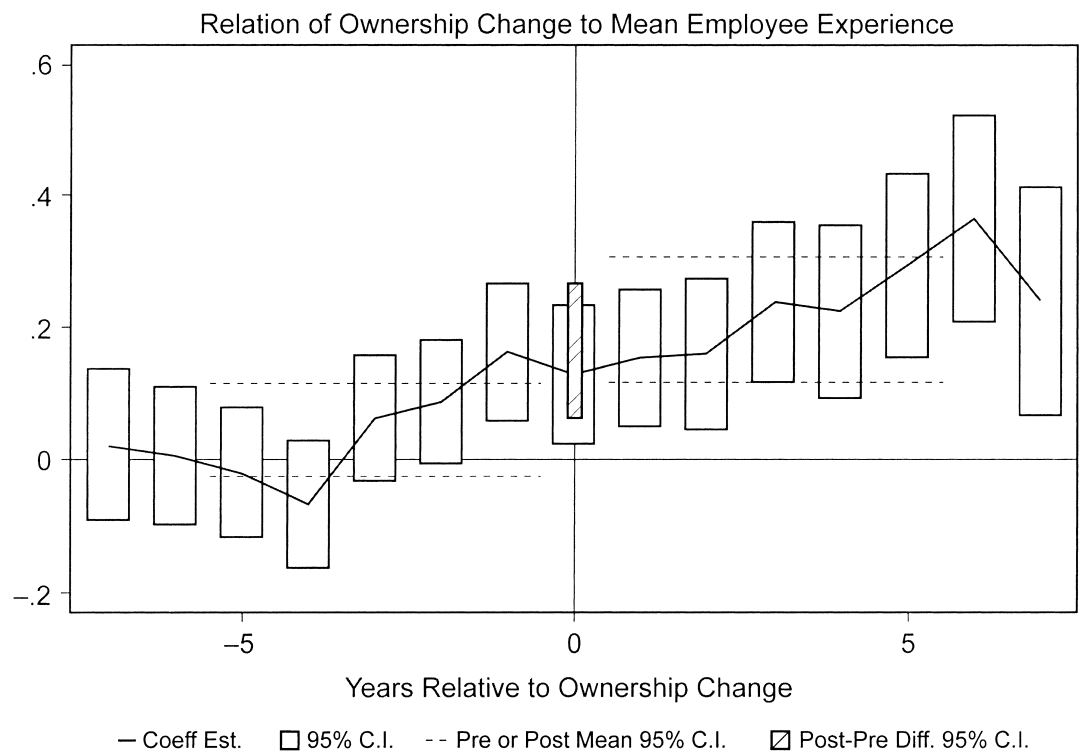

Fig. 11.6 Graph of the coefficients on the ownership change dummies in the mean employee experience equation

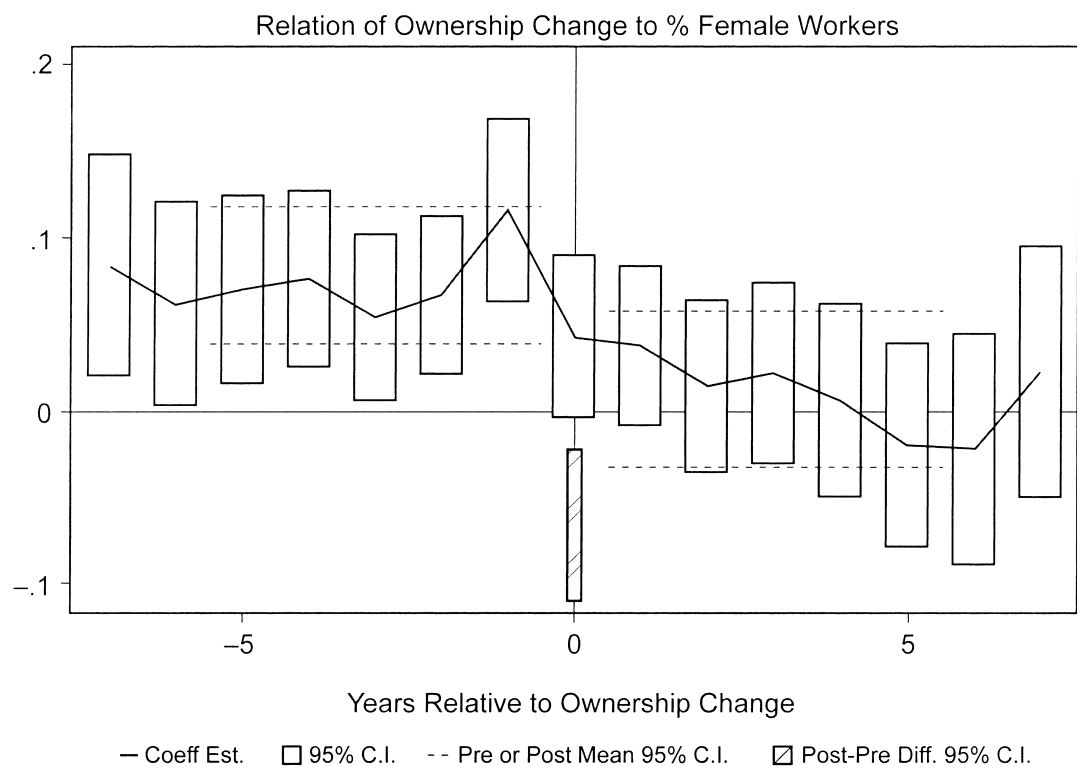

Fig. 11.7 Graph of the coefficients on the ownership change dummies in the percentage female workers equation 


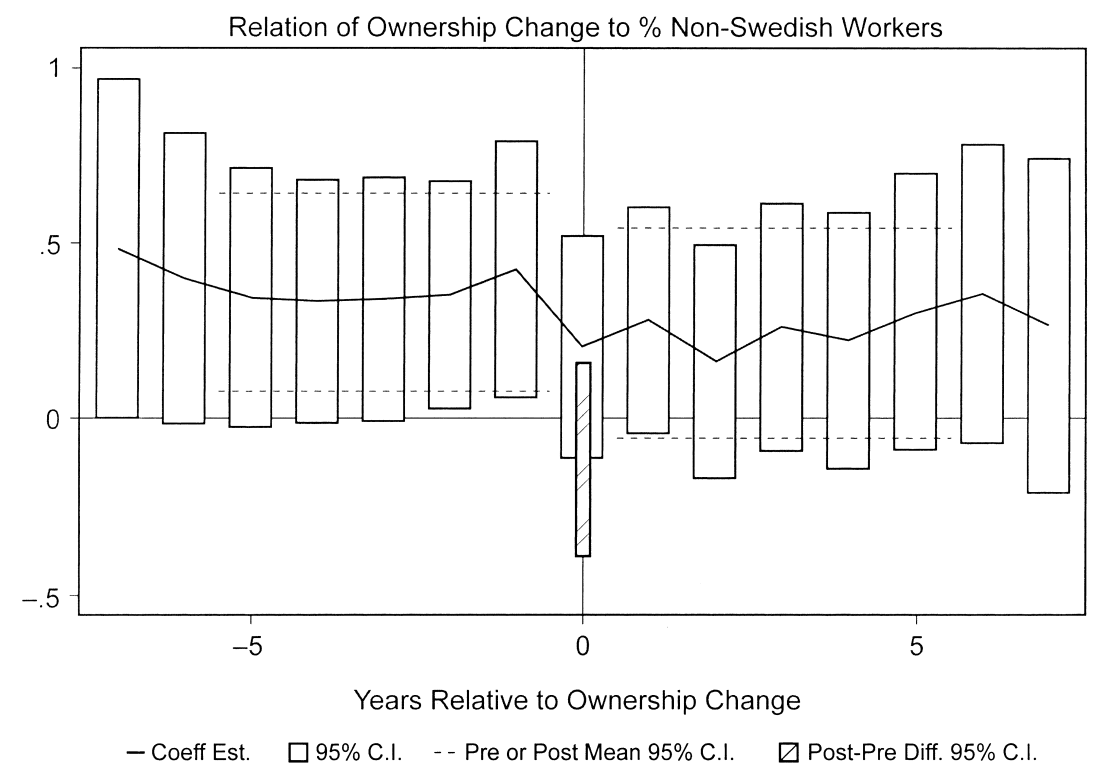

Fig. 11.8 Graph of the coefficients on the ownership change dummies in the percentage of non-Swedish workers equation

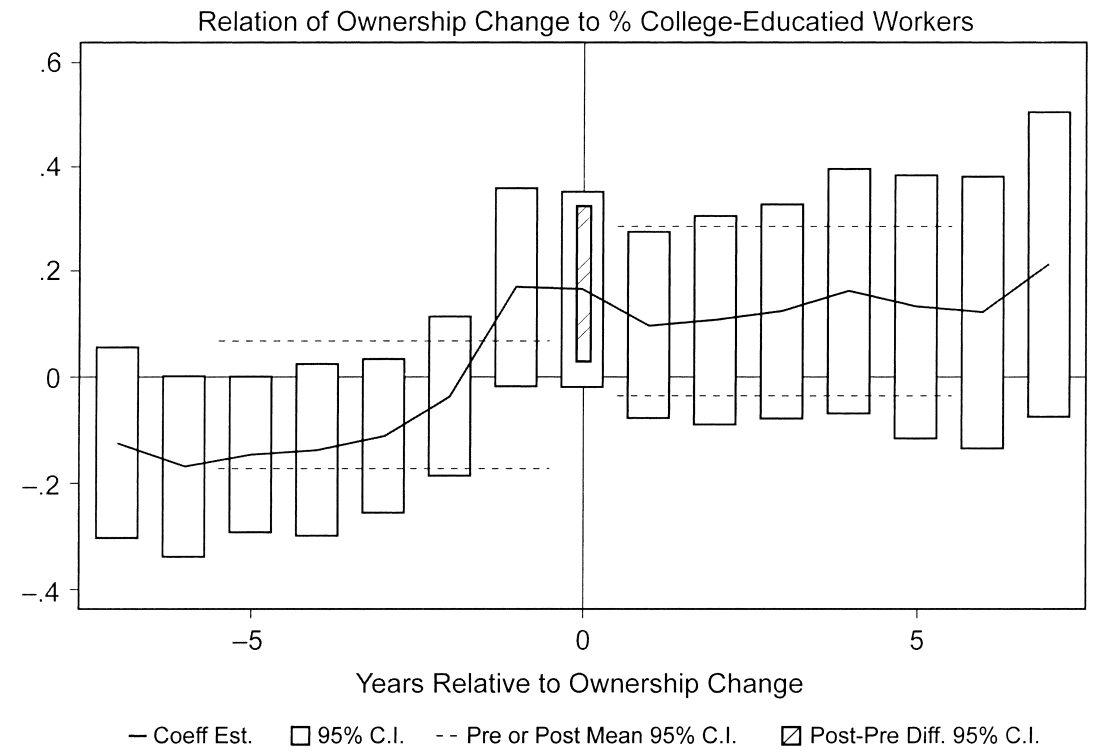

Fig. 11.9 Graph of the coefficients on the ownership change dummies in the percentage of college-educated workers equation 


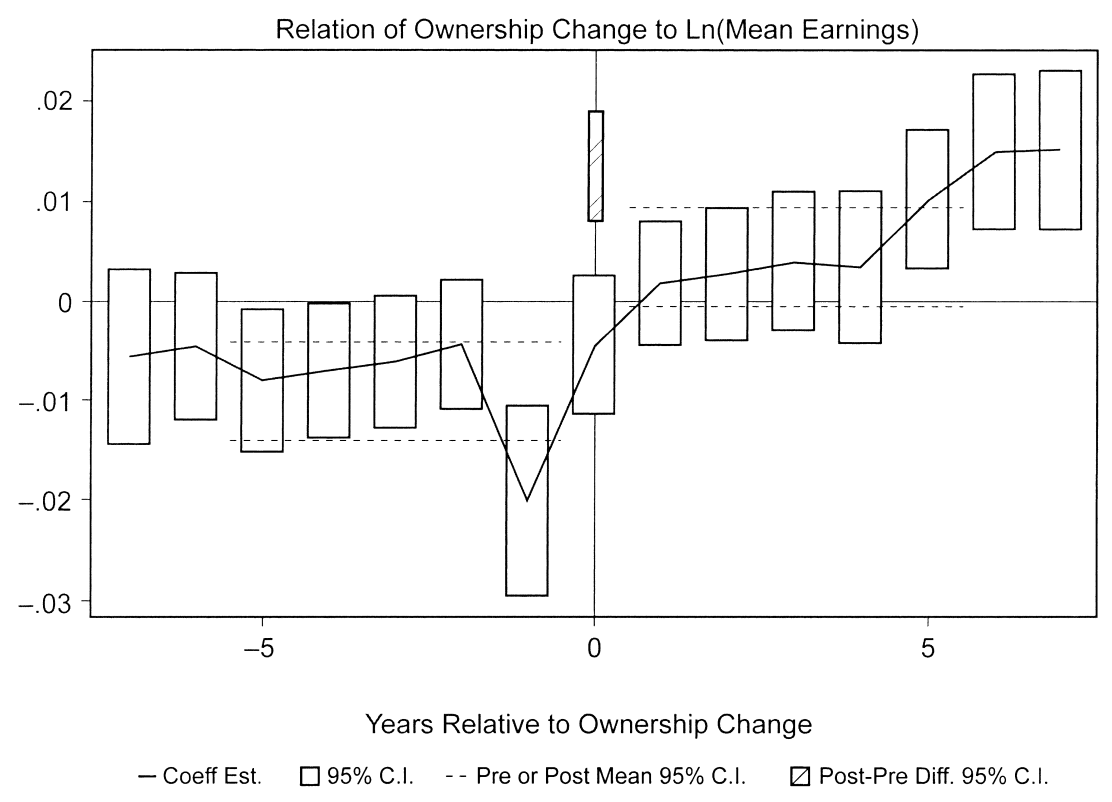

Fig. 11.10 Graph of the coefficients on the ownership change dummies in the mean earnings equation

job durations than men, and hence being more likely to lose a job because of short job tenure and experience.

The annual estimated coefficients in figures 11.5 through 11.10 reaffirm the previous conclusions, but suggest that at least some of the estimated changes were gradual processes. In particular, mean employee age and experience increased gradually, and the percentage of female workers declined gradually over a period of several years following ownership change. There are multiple possible interpretations of these patterns, but one interpretation involves employees not fully losing their connection with a plant even if they were laid off temporarily during the year of ownership change, and the new owners often gradually shifting to a workforce that suits their demands.

Two additional stylized facts emerge from these figures. The percentage of college-educated workers may actually have increased in the year before ownership change, although the ranges of error involved leave some uncertainty in this conclusion. Also, earnings plummeted (significantly) relative to the norm in the year preceding ownership change. This decline in earnings is explained by a reduction in hours worked per employee, which fell below the norm by 3.2 percent in the year preceding ownership change 
and 1.3 percent in the year of ownership change, but in other years was close to the norm in plants that experienced ownership change. ${ }^{15}$

\subsubsection{Where Pre-Ownership Change Employees Went}

Next, we make use of the individual-level data, in order to track the movement and relative compensation of workers whose establishments were involved in an ownership change. In doing so, we attempt to answer two questions: (a) where did the old employees go? and (b) where did the new employees come from?

Table 11.11 presents statistics on the destination (if any) of employees whose plants experienced ownership change. The top panel of table 11.11 pertains to all employees who left their plant, while the second panel pertains to all employees. Each panel indicates the percentage of employees who had the following characteristics: female, non-Swedish born, age above the mean of all manufacturing employees, experience above the mean of all manufacturing employees, and three categories of educational achievement (less than high school, at least some high school, and at least some college-level study). The bottom panels of the table show the corresponding sample sizes for employees who left their plant and for all employees. ${ }^{16}$

The last column is the base case, pertaining to employees whose plants did not change owner in the subsequent year. In this and other columns in the table, observations in which ownership change occurred in the previous or following year are excluded to avoid contaminating data in nearby years. Also, the observations considered are all employee-year combinations for whom their plant meets the required categorization regarding the type of ownership change it was about to experience.

Table 11.11 confirms the findings of the plant-level analyses, concerning which types of employees were most likely to leave in the wake of an ownership change. For example, in plants experiencing ownership change, 27.45 percent of employees were female and 14.23 percent were nonSwedish born. Because a slightly higher prevalence of females, 28.07 percent, and non-Swedish born, 15.28 percent, occurred among leaving employees, the percentages of female and non-Swedish born employees was driven down slightly, consistent with the slight decreases observed in the preceding regressions. Similarly, the table shows a disproportionately low percentage of older and more experienced employees leaving plants that experienced ownership change.

15. This finding stems from a regression, like those presented in the chapter, in which the dependent variable is the logarithm of the average number of hours worked per employee at the plant. In other years relative to ownership change, the coefficients of the ownership change dummies in this regression are near zero and are statistically insignificant at the .05 level.

16. Because the years of experience and education level variables are not available for some employees, sample sizes are also reported for the number of employees for whom values of these variables are available. 
Table 11.11 Employees leaving plants in the aftermath of an ownership change: Statistics for workers at year $\boldsymbol{T}-1$ whose plants experienced an ownership change during year $T$

\begin{tabular}{|c|c|c|}
\hline Employee type & $\begin{array}{l}\text { All ownership } \\
\text { changes }\end{array}$ & $\begin{array}{c}\text { No ownership } \\
\text { change }\end{array}$ \\
\hline \multicolumn{3}{|l|}{ Employees leaving plants: } \\
\hline$\%$ Female & 28.07 & 28.50 \\
\hline$\%$ Non-Swedish & 15.28 & 14.12 \\
\hline$\%$ Age above mean & 45.35 & 39.15 \\
\hline$\%$ Experience above mean & 40.04 & 36.45 \\
\hline$\%$ Education less than high school & 38.75 & 37.30 \\
\hline$\%$ Education to high school & 47.82 & 48.91 \\
\hline$\%$ Education some college & 13.43 & 13.79 \\
\hline \multicolumn{3}{|l|}{ All employees: } \\
\hline$\%$ Female & 27.45 & 26.38 \\
\hline$\%$ Non-Swedish & 14.23 & 12.60 \\
\hline$\%$ Age above mean & 49.12 & 47.81 \\
\hline$\%$ Experience above mean & 49.72 & 50.98 \\
\hline$\%$ Education less than high school & 41.00 & 39.40 \\
\hline$\%$ Education to high school & 47.35 & 48.27 \\
\hline$\%$ Education some college & 11.64 & 12.33 \\
\hline \multicolumn{3}{|l|}{ Sample size for employees leaving plant: } \\
\hline All & 131,495 & $1,782,949$ \\
\hline With experience data & 52,952 & 802,542 \\
\hline With education data & 125,363 & $1,699,355$ \\
\hline \multicolumn{3}{|l|}{ Sample size for all employees: } \\
\hline All & 352,094 & $6,586,368$ \\
\hline With experience data & 135,380 & $2,690,062$ \\
\hline With education data & 338,494 & $6,358,300$ \\
\hline
\end{tabular}

The individual-level results qualify the plant-level results presented earlier. Table 11.11 reveals that even among plants that did not experience ownership, relatively high percentages of women and non-Swedish born employees left the plants. Thus, while ownership change may have resulted in substantial job loss for these workers, it appears as though they were not treated more unfairly in plants experiencing ownership change than in representative plants (in fact, the evidence suggests they were treated slightly more fairly, perhaps because of differing job roles). ${ }^{17}$

In tables 11.12 and 11.13, we follow workers at the end of year $T-1$ and measure their employment status and earnings growth, respectively, at the end of year $T+1$, cross-classified by a set of dummy variables denoting whether the plant that employed them during year $T-1$ experienced an

17. Some care must be taken in comparing findings at the plant and employee levels not only because of the complexity of deciphering the flows of employees, but also because the plant-level analyses control for industry, plant age, and year effects while the employee-level results simply present outcomes for average employees. 
ownership change during year $T .{ }^{18}$ In each table, the top panel pertains to employees whose plants experienced ownership change, while the bottom panel pertains to the comparator case of no ownership change. Within each panel, rows pertain to employees' future job status - workers could be employed at the same plant, at another plant owned by the previous owner, at another plant owned by the new owner, at another firm in the same industry, at another firm in a different industry, in an unknown industry or plant (which likely includes workers who become self-employed or who are employed at an entrepreneurial startup), or they could be unemployed.

The findings in table 11.12 are consistent with the plant-level results cited earlier, in the sense that ownership change appears to have been associated with an increase in worker turnover at plants and firms. For example, only 62.7 percent of the workers observed at the end of year $T-1$ whose plants changed owners during year $T$ were still employed at the same establishment at the end of year $T+1$. Turnover findings are also presented separately for different types of workers. Not surprisingly, these results imply that females, non-Swedes, younger employees, and less experienced workers were less likely than representative workers to remain at the same plant in the aftermath of an ownership change. We also find that workers with the highest levels of education had the greatest mobility across firms.

Two-year mean earnings growth for the same groups of workers is presented in table 11.13. A potentially interesting finding pertains to women's salary growth compared to the norm. Regardless whether ownership change occurred, females who remained in the same establishment had higher average earnings growth than males, presumably because they switched more frequently from part-year to full-year (or part-time to fulltime) employment. The potentially interesting pattern is that women who remained working in an establishment involved in an ownership change experienced less earnings growth relative to the norm of no ownership change (in both absolute and percentage terms) than men. It is important to note, however, that we do not have individual-specific information on hours worked. Thus, one explanation for this finding, which cannot be ruled out on the basis of our empirical analysis, is that women (who may relatively often have worked part-time) may have worked more hours in the aftermath of an ownership change.

18. The focus on years $T-1$ and $T+1$, rather than times separated by only one year, is necessitated by the timing of when ownership changes occur and when employee information is reported. Recall that employee information pertains to November, while ownership change can occur at any time during the reporting year. If years $T-1$ and $T$ were used, it would be possible that ownership change could have occurred after the employee data were received in year $T$ (not to mention that new owners' policies may take some time to come into effect). If years $T$ and $T+1$ were used, the employee's initial status normally would be recorded after ownership change occurred rather than before. 


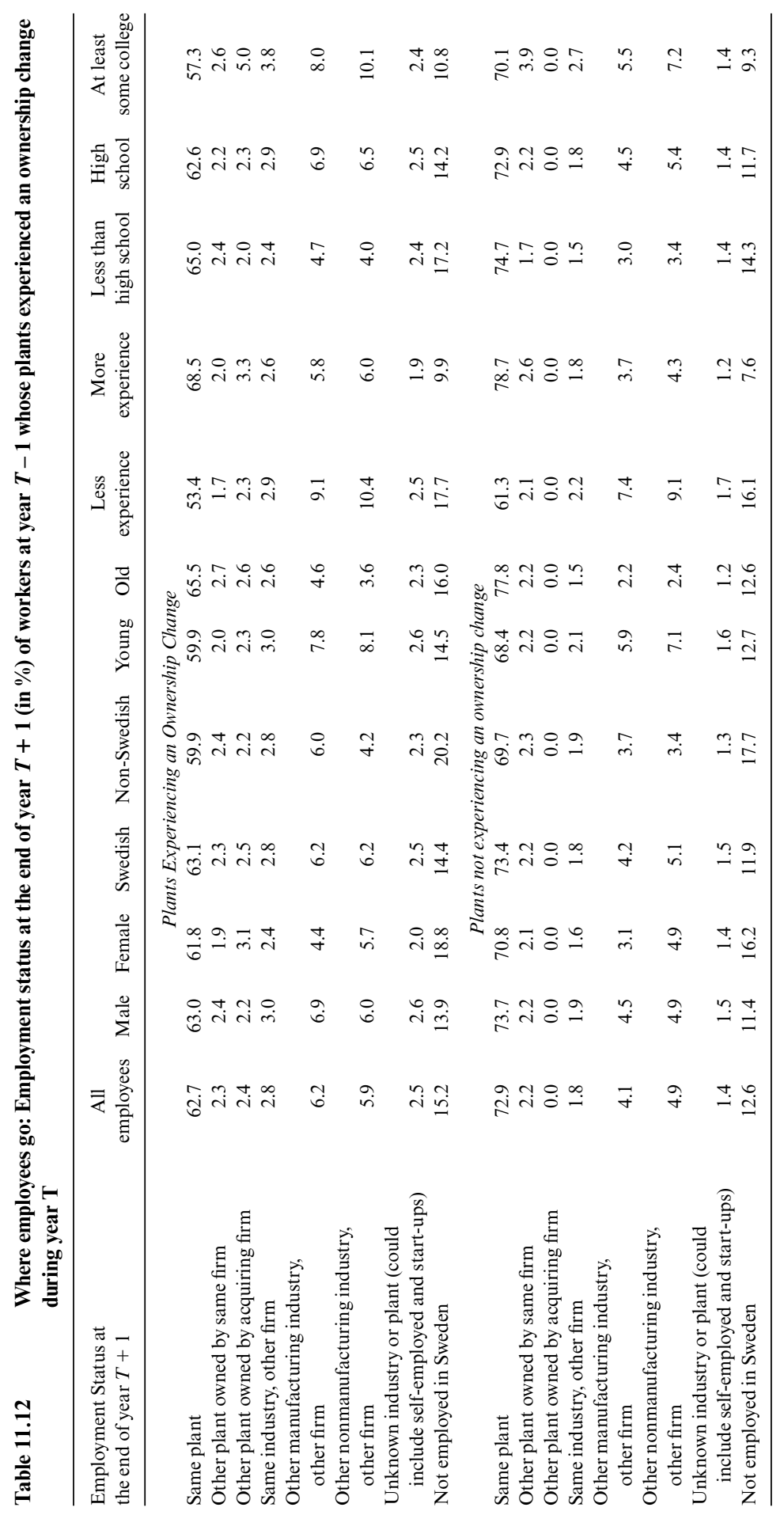




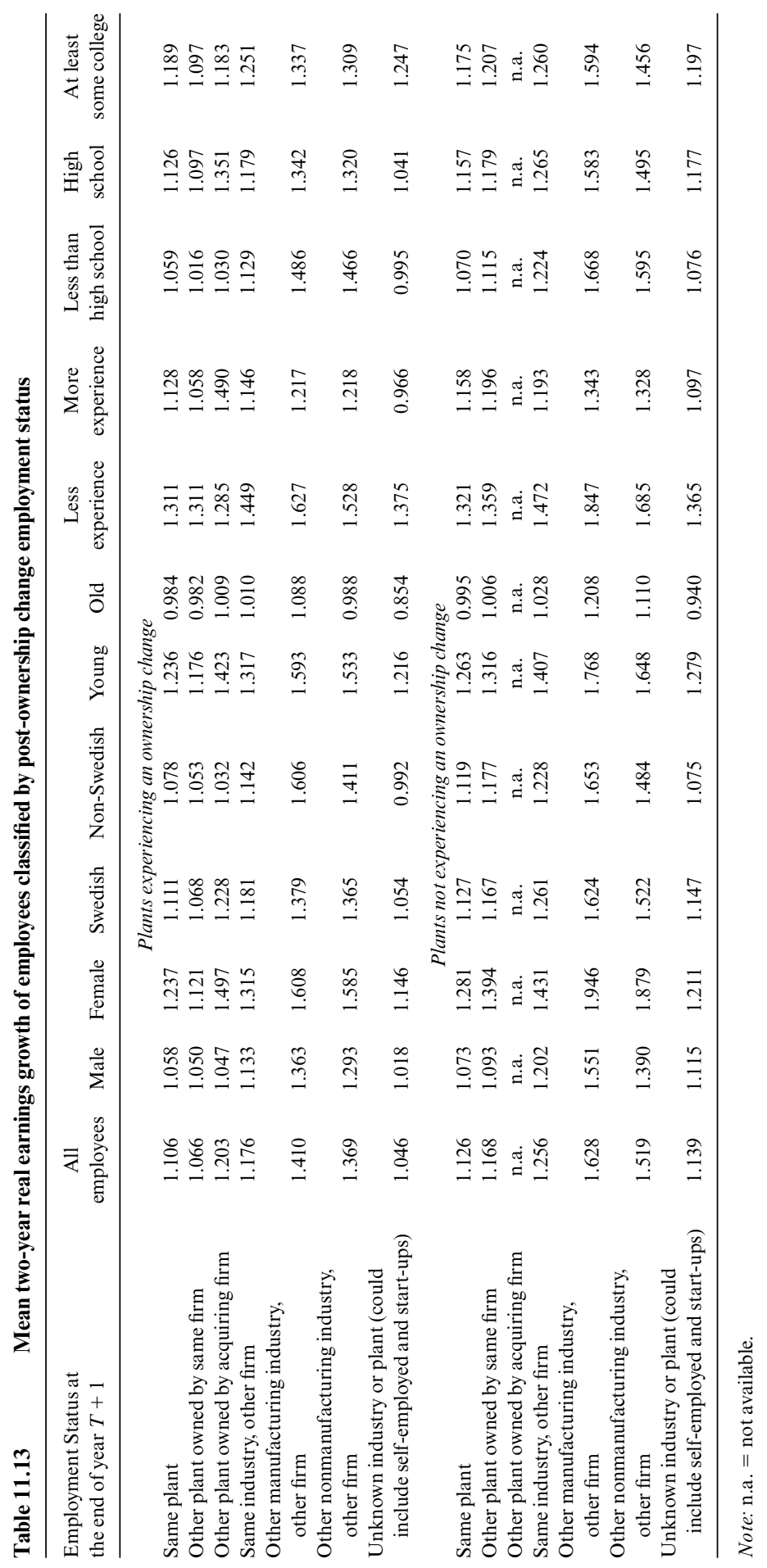


It is not only women who experienced this relative wage growth disadvantage associated with ownership change. Similarly, earnings growth relative to the norm was lower for non-Swedish born and younger employees, compared to Swedish born and older employees, who remained at the establishment.

We also find that more experienced employees had lower earnings growth relative to the norm than did less experienced workers. Employees with at least a college education were the only group of staying employees to experience higher earnings growth with ownership change than without. Again, perhaps surprisingly, employees without a high-school education experienced higher earnings growth relative to the norm than those with a high-school education. These results should be interpreted with caution, since they may be influenced by shifts in work hour patterns. They also reflect diverse percentages of staying employees and are derived from aggregate statistics.

Earnings growth was low, relative to the norm, for employees who left an establishment that experienced ownership change. For example, employees who moved to another firm in the same industry had only 17.6 percent average wage growth if they began in ownership change establishments, versus 25.6 percent average wage growth if they began in establishments that did not experience ownership change. The difference may reflect lower average human capital among leaving employees as well as possible difficulties of job changes triggered by ownership change.

\subsubsection{New Hires by Plants That Experienced an Ownership Change}

Table 11.14 contains descriptive statistics on workers at plants that recently experienced an ownership change. Consistent with the format of table 11.11, we present percentages by employee type for employees hired by plants during the previous year (new hires) in the top panel, followed by the same percentages for all workers employed at these establishments in the second panel. Note that these figures once again are presented separately for plants involved in an ownership change and those that did not experience such an event.

The evidence in the top panel implies substantial differences between these two types of plants, in terms of the kind and fraction of workers they hired. These substantial differences existed despite only small differences (second panel) in the composition of the workforce between ownership change and no ownership change plants. Plants that recently experienced an ownership change more often hired older, more experienced, and less educated workers. Also, these findings, in conjunction with the results in table 11.11 on the characteristics of employees who leave plants (we do not use the term fired as we cannot distinguish between voluntary and involuntary actions), suggest that job turnover was higher in ownership change establishments, especially for these types of workers. 

Table 11.14 Recently hired employees: General statistics for workers at year $T+1$
whose plants experienced an ownership change during year $T$

\begin{tabular}{lcc}
\hline Employee type & $\begin{array}{c}\text { All ownership } \\
\text { changes }\end{array}$ & $\begin{array}{c}\text { No ownership } \\
\text { change }\end{array}$ \\
\hline Recently hired employees (between & & \\
$\quad$ year $T$ and $T+1$ ): & 28.13 & 27.99 \\
\% Female & 12.53 & 13.16 \\
\% Non-Swedish & 37.09 & 25.45 \\
\% Age above mean & 41.94 & 33.12 \\
\% Experience above mean & 31.72 & 26.86 \\
\% Education less than high school & 52.56 & 55.01 \\
\% Education to high school & 15.72 & 18.13 \\
\% Education some college & & \\
All employees: & 27.70 & 26.14 \\
\% Female & 13.08 & 12.33 \\
\% Non-Swedish & 49.58 & 48.75 \\
\% Age above mean & 57.09 & 57.16 \\
\% Experience above mean & 38.10 & 36.62 \\
$\%$ Education less than high school & 49.11 & 49.84 \\
\% Education to high school & 12.78 & 13.54 \\
\% Education some college & & \\
Sample size for employees coming to plant: & 123,789 & $1,507,679$ \\
All & 65,410 & 910,481 \\
With experience data & 120,071 & $1,445,262$ \\
With education data & 351,269 & \\
Sample size for all employees: & 156,689 & $6,239,988$ \\
All & 343,979 & $2,858,277$ \\
With experience data & & $6,090,512$ \\
With education data & & \\
\hline
\end{tabular}

In table 11.15 , we reverse the analysis of table 11.12 by identifying workers at the end of year $T+1$ and then determining their employment status at the end of year $T-1$. The results presented in table 11.15 imply that plants involved in an ownership change were more likely to hire new workers than plants that did not experience these transactions. There is also an element of consistency with the regression results presented earlier, which indicated that ownership change was associated with downsizing of the workforce. That is, while three quarters of workers (75.8 percent) at plants not experiencing an ownership change were still employed at the same plant, only two thirds (64.8 percent) of workers whose establishment changed owners in the previous year remained employed at the same facility.

Table 11.16 presents the two-year mean earnings growth of workers identified at the end of year $T+1$. The high wage growth apparent for employees coming from other nonmanufacturing industries and from unknown industries or plants reflects the fact that employees from these sources previously earned much less than other employees, which stems 


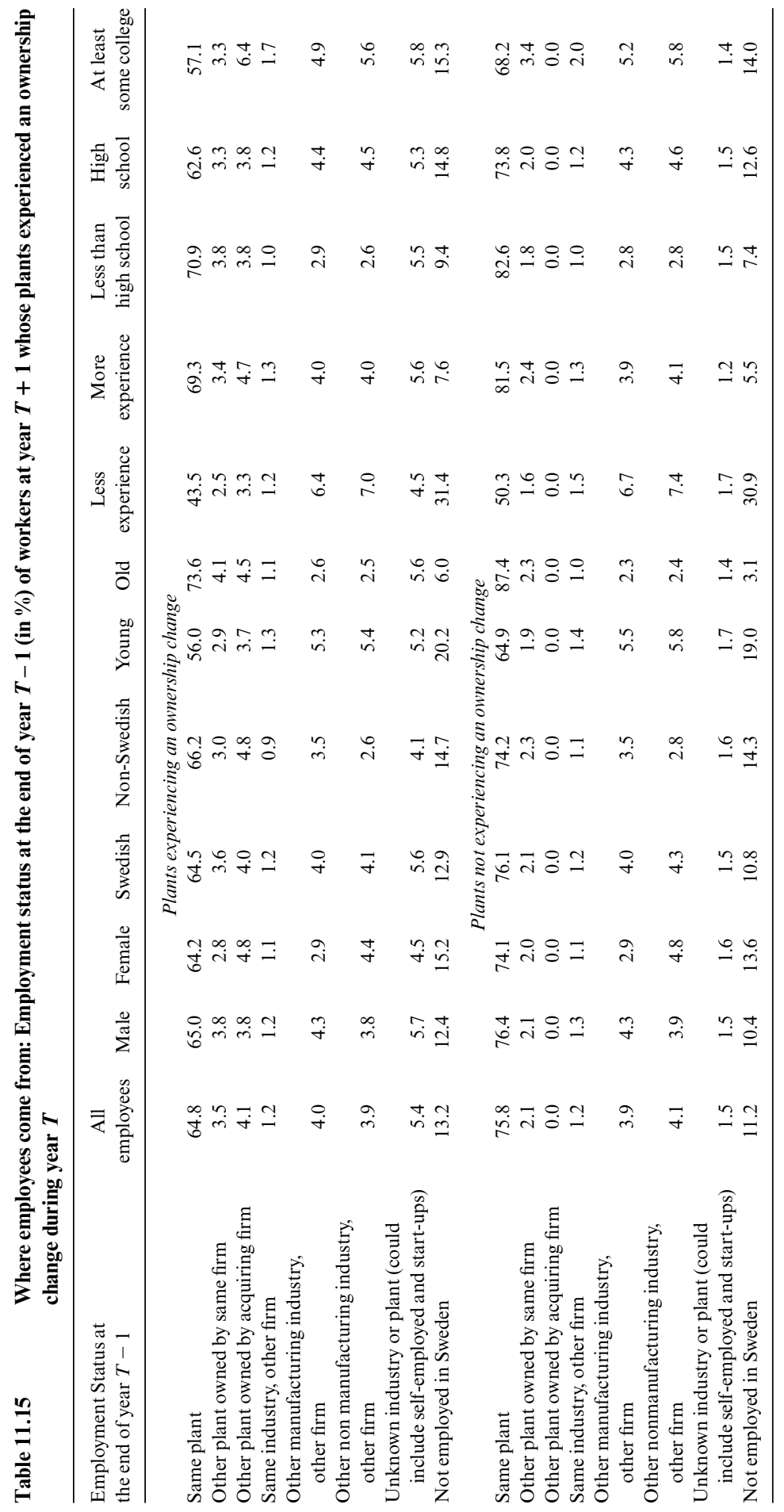




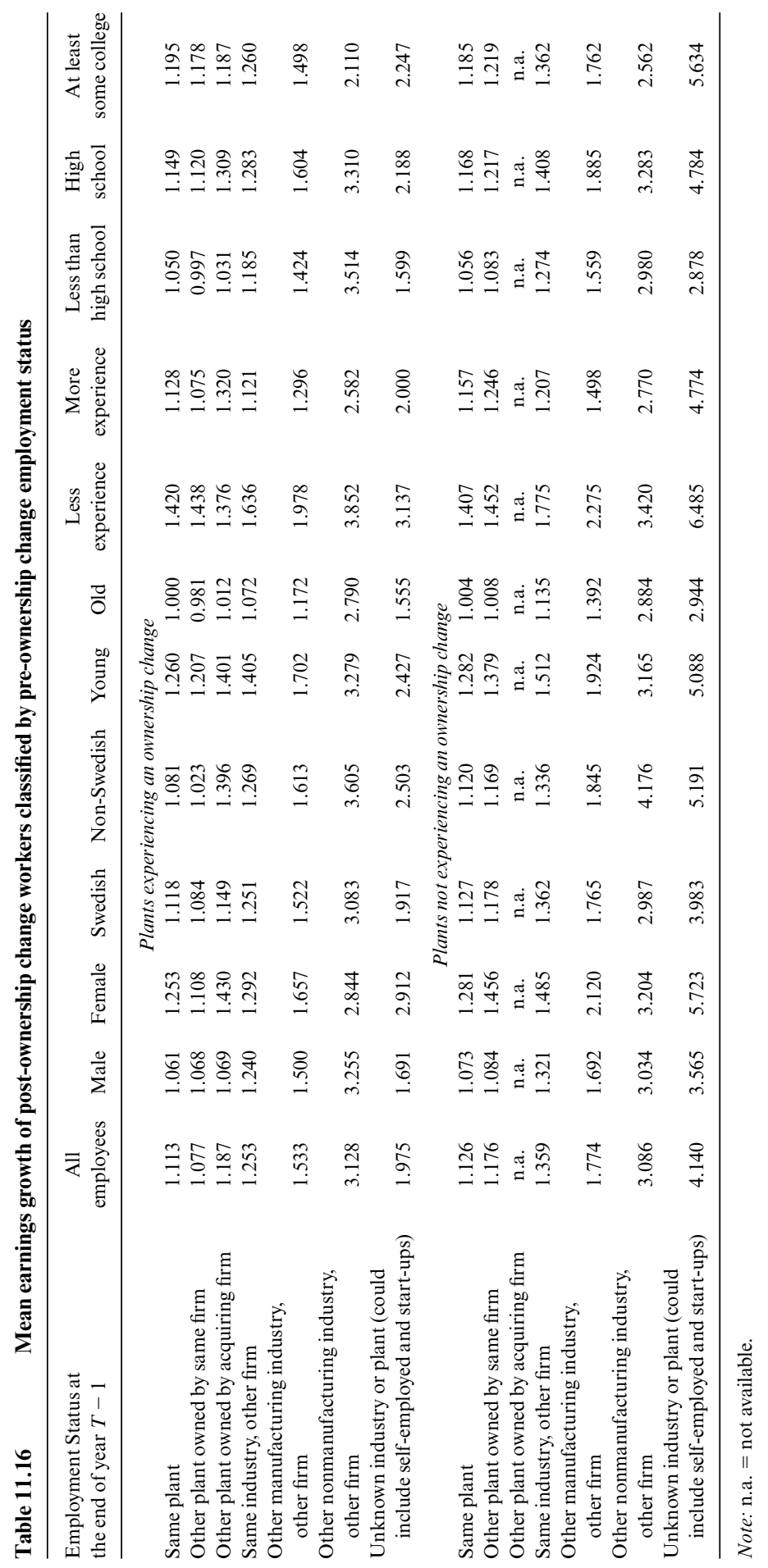


from some combination of fewer working hours (some may have just entered the workforce) and lower salaries. ${ }^{19}$ The patterns in tables 11.15 and 11.16 indicate greater mobility and higher earnings growth for Swedish employees, younger and less-experienced workers, and employees with higher levels of education.

We find that new employees in ownership change plants experienced lower earnings growth than employees being hired by other plants. Our findings also imply that this relative earnings differential was greater for women, non-Swedish born employees, young employees, experienced employees, and non-college-educated employees than for male, Swedishborn, young, inexperienced, and college-educated employees.

\subsection{Conclusions}

In this chapter, we have generated some stylized facts concerning the average consequences of ownership change for productivity and investment in human capital. The empirical analysis is based on a rich matched employer-employee data set, containing information on 19,010 Swedish manufacturing plants for the years 1985 to 1998. As such, this chapter is the first plant-level study based on evidence from continental Europe and the first analysis of ownership change (in any country) using matched employer-employee data. In contrast to existing plant-level studies, we use more robust econometric methods that adjust for survivor and measurement error biases.

The results support theories of ownership change predicting improved economic performance. Our findings are consistent with recent theoretical and empirical evidence (see Jovanovic and Rousseau 2002; Maksimovic and Phillips 2001, 2002) suggesting that takeovers and asset sales result in the reallocation of a firm's resources to more efficient uses and to better managers. We find that establishments averaged 7 percent lower total factor productivity, and 2 percent lower labor productivity, than comparable plants just before a change in ownership and steadily improved to normal productivity thereafter. Short-term patterns (five years before and after transactions) differed from long-term patterns (ten years before and after

19. For example, among all employees who experienced ownership change, those coming from a nonmanufacturing industry in another firm earned in the base year only 30 percent of the inflation-adjusted mean earnings, and those from an unknown industry or plant earned in the base year only 52 percent of the inflation-adjusted mean earnings. These mean earnings are below those for all other employee source categories in the table. Employees from another manufacturing industry and firm earned in the base year 65 percent of the inflationadjusted mean earnings, employees from another firm in the same industry earned 89 percent, employees from the same plant earned 92 percent, employees from the acquired firm earned 94 percent, and employees from another plant of the acquiring firm earned 102 percent. As these percentages suggest, employees entering plants that experienced ownership change tended to earn slightly below the economy-wide mean when not controlling for industry- or occupation-specific components of earnings. 
transactions) and varied substantially over individual years, a stylized fact that underscores the benefit of having a long annual panel.

Plants involved in an ownership change had higher output and employment before the transaction. The increase in labor productivity after the transfer of ownership appears to be the result of a decline in output, combined with an even larger reduction in employment. These patterns emerge most strongly for full acquisitions and divestitures and unrelated acquisitions.

We also find that plants involved in an ownership change experienced an upgrading in the quality of human capital. That is, we observe increases in average employee age, experience, and the percentage of employees with a college education. Ownership change also led to an increase in earnings and a reduction in the percentage of female workers.

Our analysis of individual-level data allows us to directly track the movement and relative compensation of workers whose establishments were involved in an ownership change. Several stylized facts emerge from this analysis. It appears that ownership change resulted in substantial job loss for women and non-Swedish employees. However, a more comprehensive analysis reveals that turnover rates among such employees were also high in plants that did not experience an ownership change.

We also find that employees who leave a plant in the aftermath of ownership change tend to be less experienced, younger workers. It is important to note that Sweden has influential unions, with a membership rate of about 70 percent. Collective agreements, which regulate some firing procedures, could lead to a last-in, first-out policy that might have driven the tendency for younger, less experienced workers to leave. ${ }^{20}$ Indeed, this pattern also explains the high job loss for women and non-Swedes, since these employees tend to be relatively inexperienced with shorter job tenure.

Another stylized fact is that highly-educated workers appear to be the most mobile employees. The findings also imply that women, foreign-born, and young workers employed at plants involved in an ownership change experience greater job loss and reductions in earnings than comparable workers at plants that are not involved in such transactions. The latter result should be interpreted with caution because we do not have data on hours worked.

In future work, we hope to implement the robustness tests outlined in Van Biesebroeck (2004) by employing nonparametric and semiparametric methods to compute productivity and then reestimating the various

20. It is rare for a company to opt out of a collective agreement. How rare that is is reflected in the case of the retail chain Toys R Us. When the firm opened its first stores in Sweden, the $\mathrm{CEO}$ refused to sign the collective agreement for retail workers. Their refusal to do so was front page news in Sweden for several weeks. This led to a boycott of the company by other unions, which meant that painters, carpenters, electricians, and other skilled workers refused to work for them. After losing money due to the boycott, they signed the agreement. 
econometric models. Given our large sample size, we can also analyze whether there are significant differences across industrial sectors in the impacts of ownership change on economic performance and human capital. Finally, it would be useful to discriminate among the three theories that predict a positive effect of ownership change on economic performance: agency theory, matching theories of ownership change, and the capital upgrading theory of ownership change.

\section{References}

Baldwin, J. R. 1998. The dynamics of industrial competition. Cambridge: Cambridge University Press.

Bartelsman, E. J., and M. Doms. 2000. Understanding productivity: Lessons from longitudinal microdata. Journal of Economic Literature. 38 (3): 569-94.

Bhagat, S., A. Shleifer, and R. W. Vishny. 1990. Hostile takeovers in the 1980s: The return to corporate specialization. Brookings Papers on Economic Activity, Microeconomics: $1-72$.

Brown, C., and J. L. Medoff. 1988. The impact of firm acquisition on labor. In Corporate takeovers: Causes and consequences, ed. A. J. Auerbach, 9-32. Chicago, IL: University of Chicago Press.

Caves, R. E. 1998. Industrial organization and new findings on the turnover and mobility of firms. Journal of Economic Literature 36 (4): 1947-82.

Conyon, M., S. Girma, S. Thompson, and P. W. Wright. 2001. Do hostile mergers destroy jobs? Journal of Economic Behavior and Organization 45 (4): 427-40.

. 2002. The impact of mergers and acquisitions on company employment in the United Kingdom. European Economic Review 46 (1): 31-49.

Fisher, F. M., and J. McGowan. 1983. On the misuse of accounting rates of return to infer monopoly profits. American Economic Review 73 (1): 82-97.

Gort, M. 1969. An economic disturbance theory of mergers. Quarterly Journal of Economics 83 (4): 624-42.

Gugler, K., D. C. Mueller, B. B. Yurtoglu, and C. Zulehner. 2003. The effect of mergers: An international comparison. International Journal of Industrial Organization 21 (5): 625-53.

Gugler, K., and B. B. Yurtoglu. 2004. The effect of mergers on company employment in the USA and Europe. International Journal of Industrial Organization 22 (4): 481-502.

Harris, R. D. S. Siegel, and M. Wright. 2005. Assessing the impact of management buyouts on economic efficiency: Plant-level evidence from the United Kingdom. The Review of Economics and Statistics 87 (1): 148-53.

Hayward, M. L. A., and D. C. Hambrick. 1997. Explaining the premiums paid for large acquisitions: Evidence of CEO hubris. Administrative Science Quarterly 42 (1): 103-27.

Holmes, T. J., and J. A. Schmitz, Jr. 1990. A theory of entrepreneurship and its application to the study of business transfer. Journal of Political Economy 98 (2): 265-94.

Jensen, M. C. 1988. Takeovers: Their causes and consequences. Journal of Economic Perspectives 2 (1): 21-48. 
1993. The modern industrial revolution: Exit and the failure of internal control systems. Journal of Finance 48:831-80.

Jovanovic, B. 1979. Job matching and the theory of labor turnover. Journal of Political Economy 87 (5): 972-90.

Jovanovic, B., and P. Rousseau. 2002. Mergers as reallocation. NBER Working Paper no. 9279. Cambridge, MA: National Bureau of Economic Research, October.

Lichtenberg, F. R., and D. Siegel. 1987. Productivity and changes in ownership of manufacturing plants. Brookings Papers on Economic Activity 1987 (3): 643-73. . 1990a. The effect of leveraged buyouts on productivity and related aspects of firm behavior. Journal of Financial Economics 27 (1): 165-94.

- 1990b. The effect of ownership changes on the employment and wages of central office and other personnel. Journal of Law and Economics 33 (2): 383 408.

Link, A., and D. S. Siegel. 2007. Innovation, entrepreneurship, and technological change. Oxford, U.K.: Oxford University Press.

Maksimovic, V., and G. Phillips. 2001. The market for corporate assets: Who engages in mergers and asset sales and are there efficiency gains? Journal of Finance 56 (6): 2019-65.

-2002. Do conglomerate firms allocate resources inefficiently across industries: Theory and evidence. Journal of Finance 57 (2): 721-67.

Manne, H. 1965. Mergers and the market for corporate control. Journal of Political Economy 73 (2): 110-20.

McGuckin, R. H., and S. V. Nguyen. 1995. On productivity and plant ownership change: New evidence from the longitudinal research database. RAND Journal of Economics 26 (2): 257-76.

- 2001. The impact of ownership change: A view from labor markets. International Journal of Industrial Organization 19 (5): 739-62.

McGuckin, R. H., S. V. Nguyen, and A. P. Reznek. 1998. On the Impact of Ownership Change on Labor: Evidence from Food Manufacturing Plant Data. In Labor statistics measurement, National Bureau of Economic Research, Studies in Income and Wealth, Volume 60, J. Haltiwanger, M. Manser, and R. Topel, ed., 20746. Chicago, IL: University of Chicago Press.

McWilliams, A., and D. Siegel. 1997. Events studies in management research: Theoretical and empirical issues. Academy of Management Journal 40 (3): 626-57.

Meade, J. E. 1968. Is "The New Industrial State" Inevitable? Economic Journal 78 (310): 372-92.

Mueller, D. C. 1969. A theory of conglomerate mergers. Quarterly Journal of Economics 83 (4): 643-59.

Ravenscraft, D. J., and F. M. Scherer. 1987. Mergers, sell-offs, and economic efficiency. Washington, D. C.: The Brookings Institution.

Roll, R. 1986. The hubris hypothesis of corporate takeovers. Journal of Business 59 (2): 197-216.

Schoar, A. 2002. Effects of corporate diversification on productivity. Journal of Finance 57 (6): 2379-2403.

Shleifer, A. 2001. Inefficient markets. New York: Oxford University Press.

Siegel, D. S. 1999. Skill-biased technological change: Evidence from a firm-level survey. W. E. Upjohn Institute for Employment Research, Kalamazoo, MI: W. E. Upjohn Institute Press.

Van Biesebroeck, J. 2004. Robustness of productivity estimates. NBER Working Paper no. 10303. Cambridge, MA: National Bureau of Economic Research, January. 